\title{
STUDIES ON COLUMBELLIDAE
}

by EVELINE and ERNST MARCUS.

(with 8 plates)

\section{Contents}

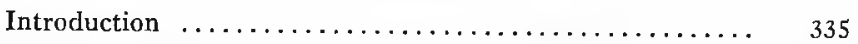

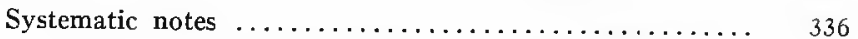

1. Anachis brasiliana (p. 337). 2. A. sparsa (p. 338).

3. A. obsea (p. 339). 4: A. veleda (p. 337). 5. Nitidella dichroa (p. 338), 6. Mitrella lunata (p. 339).

7. Columbella mercatoria (p. 340). 8. C. rustica (p. 342).

General remarks on the shells $\ldots \ldots \ldots \ldots \ldots \ldots \ldots \ldots . . \ldots \ldots$

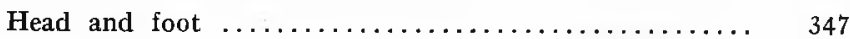

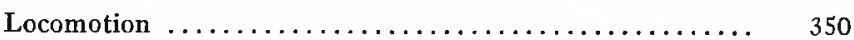

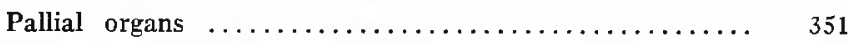

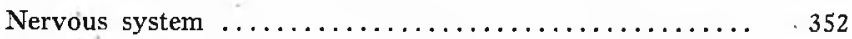

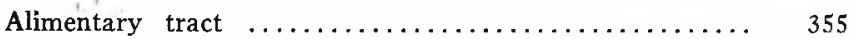

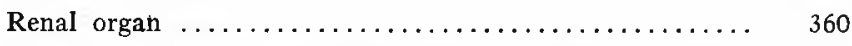

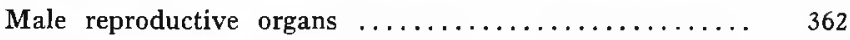

Female reproductive organs $\ldots \ldots \ldots \ldots \ldots \ldots \ldots \ldots .36$

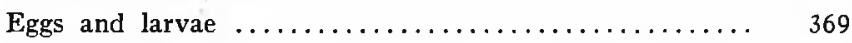

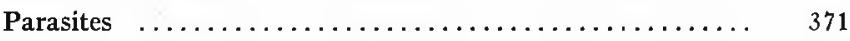

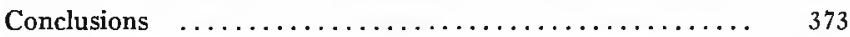

Resumo .............................. 376

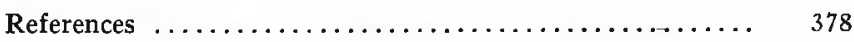

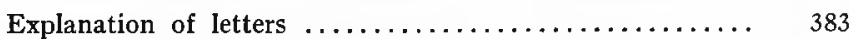

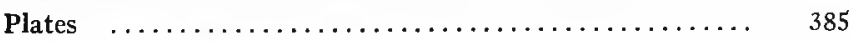

\section{INTRODUCTION}

The exterior aspect of the soft parts of a Columbella, C. rustica (L.), was drawn and rapidly described more than 100 years ago (Joannis, 1834), but the classical French papers of the last decennia of the past century which constitute the basis of modern malacology do not include the Columbellidae. Thiele (1924, p. 208) still called. 
the anatomy of the columbellids unknown, and 30 years later Risbec (1954) began his study of the inner organs of 6 columbellids from the coast of New Caledonia with the words: "l'anatomie des Columbellidae est complètement inconnue". Risbec's conditions for work (1937, p. 189-192) allowed only for an anatomical foretaste without nicrotomy. Hence we took the opportunity to continue his studies, but with 8 other species, mainly from the coast of São Paulo.

We are grateful to the Director of the Oceanographic Institute, Dr. Ingvar Emilsson, for his permission to stay repeatedly at the Base of Research, $14 \mathrm{~km} \mathrm{~W}$ of Ubatuba, whose Head, our friend Dr. Edmundo Nonato, made our work most agreeable.

Drs. Roger Jean Lavallard and Edmund Hobart Smith found a locality where Columbella mercatoria was obtained, and collected many specimens for us. We are most thankful to them, because some particularities of $C$. mercatoria and also of $C$. rustica which we owe to the Zoological Station of Naples extended our knowledge of the anatr.my and biology of the columbellids.

We thank Dr. Woutera S. S. van der Feen van Benthem Jutting-Amsterdam for her elucidative information by letter, and Dr. Germaine L. Warmke-Puerto Rico for her and Dr. Abbott's book on Caribbean Seashells (1961). This most recent synopsis of a neighbouring fauna serves to classify also Brazilian shells.

\section{SYSTEMATIC NOTES}

As 100 years ago, Reeve's Shakespearean motto (1859) holds to-day for the Columbellidae: "mis-shapen chaos of well seeming forms". Certainly Pace's list (1902b) is the first step to bring order into this chaos. Comparative revision, however, must be done with a great collection as basis and the possibility to loan further material. Since Thiele's survey $(1931$, p. 302-305) the number of taxa has increased considerably, as the "Zoological Record" shows as well as any regional list, e. g., Macpherson and Chapple's of the columbellids of Victoria (1951, p. 131). Therefore we leave aside the discussion of genera, subgenera and sections, adopt the nomenclature of Abbott (1955), and try to evidence that we combined uniform and recognizable material with every name. Hence we describe shells, colours of soft 
parts, and radulce mirely as far as seen in our material. The first 6 of our species were collected on algae, chiefly Sargassum cymosum stenophyllum immediately beneath the low water-line, $14 \mathrm{~km} \mathrm{~W}$ of

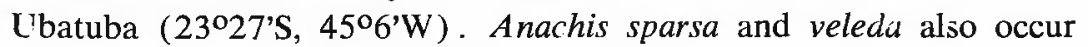
. $c$ and under stones in the vicinity of the algae. A female of veleda laid an egg capsule in a dish (1-I-1961) and so made possible to identify capsules found on Sargassum. Other capsules which we combine (see chapter "Eggs and larvae") with $A$. brasiliana and $A$. sparsa cccurred in winter (July 1960) and summer (December 1960-Jartuary 1961) on Sargassum. The egg capsules were fixed to the young broad "leaves" of the short lateral branches near the holdfast which arc smooth, not overgrown by polychaetes, bryozoans, and compound ascidians.

Columbella mercatoria was found among algae, chiefly Acanthophora spicitera, grown on stones and boulders at the mean low vater-line on the continental coast of the Canal of São Sebastião. The point, called Ponta da Prainha, is $23^{\circ} 45^{\prime} \mathrm{S}, 45^{\circ} 25^{\prime} \mathrm{W}$.

On the inside of the shells of living columbellids the co'our pattern of the outside appears by translucence. We collected prircipally live snails whose shells are still translucent after preserving or drying. Some shells inhabited by hermit crabs were also taken. Their inner layer is opaque. We did not gather dry shells from the beach, because they are generally much lighter, and the grinding action of waves and sand can modify the sculpture to such a degree that classification becomes insecure, e. g. in Anachis cancellata (Gaskoin, 1851) (see Kobelt, 1897, p. 226).

\section{Anachis brasiliana (v. Martens, 1897) (Fig. 1)}

Length up to $11 \mathrm{~mm}$, breadth about $4 \mathrm{~mm}$, smallest shells seen $5 \mathrm{~mm}$. About 9 whorls, 4 of which, smooth and convex, are nuclear. Outline of shell straight, even, only axial ribs of body whorl project slightly on the sides. Body whorl with about 12 ribs ending in front of suture. Ribs narrower than interspaces. Other whorls smooth. Spiral lines absent, except on base of body whorl. Young shells with incipient ribs behind outer lip. Aperture narrow, elliptical, with thickened varix on outer lip. Flattening behind varix may suppress 
up to 7 ribs. Inside of outer lip with 7-9 denticles, sometimes the 2nd from behind biggest. Inner lip frequently with white callus which bears a longitudinal crest.

Dry shells may have opaque, sometimes iridescent inside. Proteconch, including apex, light. Suture with white band in front; rest of shell generally whitish with many rusty brown meshes of different, scmetimes considerable, width and light spots between. Some shells are quite dark. The ribs are often light.

Siphon white, mottled, or with 3 black rings. Tentacles white with black base and a black ring farther in front. Proboscis white. Foot with brownish and greyish spots, in front with black and yellow pattern. Mantle under shell black up to apex. Operculum oval, colourless or light yellow.

\section{Discussion of Anachis brasiliana}

Our material agrees with v. Martens' description (1897, p. 171172) and figure (pl. 16, f. 10). His and our shells differ by smooth interspaces between the ribs from $A$. avara (Say, 1826). Also in $A$. avara semiplicata (Stearns, 1873), a hypotype of which was figured by Puffer and Emerson (1953, pl. 56, f. 7), spiral lines occur in these interstices.

Similar to $A$. brasiliana is Columbella sertulariarum d'Orbigny (1841, p. 431; 1846, pl. 61, f. 13-17), whose distribution Carcelles (1944, p. 253) gives from Key West and the Antilles to Brazil, Uruguay, and Argentina, Gulf of San Matias. The shell of this species is a little bigger than that of brasiliana, and the colour of the body differs slightly.

Distribution: Brazil: Bahia (v. Martens), São Paulo, Ubatuba (present material), Sta. Catharina (v. Martens); Uruguay (id.).

\section{Anachis sparsa (Reeve, 1859) (Fig. 2)}

Length $8-9 \mathrm{~mm}$, breadth $4 \mathrm{~mm}$; smallest shells of $2 \mathrm{~mm}$ have already some brown marks. Protoconch smooth, light, comprising 3 whorls with impressed, sometimes dark suture. Total number of whorls about 8. Axial ribs broader than interspaces, end in front of suture. Faint spiral lines between the ribs; base with stronger 
spiral lines. Number of ribs on body whorl about 16. Aperture small, narrowed behind; outer lip frequently with varix and regularly with dorsal flattening which may suppress up to 7 ribs. Inside of cuter lip with 6-7 denticles. Inner lip with or without callus, whose presence or absence is independent of age. On callus, when present, a row of about 6 denticles corresponding to basal spirals.

Periostracum thick, longitudinally fibrous. Some shells vitreous with colour pattern translucent on inside, others opaque and with iridescent inside. Ground colour whitish; a white stripe in front of suture. On the ribs chestnut brown or darker marks alternating with white ones, corresponding to the dark blotch of one rib a white mark Cal the two neighbouring ribs. On the basal spiral lines the brown blotches form rows or meshes.

Siphon white with grey spots or with 3-4 grey rings, tentacles white with black band, proboscis white, foot spotted, in front of operculum and at anterior border with black marks; sole with small spots and white anterior border. Mantle under shell black. Operculum yellow, rather narrow, pointed on one, broad on the other end.

\section{Discussion of Anachis sparsa}

As this species is common near Ubatuba, it should be expected in Lange's catalogue (1949). Possibly it is hidden there under the name pulchella Kiener, Sowerby, 1844, which Lange indicated (p. 96) from Guarujá near Santos. According to Johnson (1934, p. 120) this species appears with the name catenata in the literature. By comparison of our material with figures of catenata (Reeve 1859, pl. 21, f. 119a, b; Warmke \& Abbott 1961, pl. 20 r), pulchella (Warmke \& Abbott, pl. $20 \mathrm{~g}$ ), and sparsa (Reeve, pl. 31, f. 200) the differences between them become evident, and the classification of our material as sparsa is beyond doubt.

Distribution: West Indies: Brazil, coast of São Paulo, Ubatuba (present material).

3. Anachis obesa (C. B. Adams, 1845)

Up to $5 \mathrm{~mm}$ long, 2,2 $\mathrm{mm}$ broad. Whorls about $7,31 / 2$ of which nuclear and smooth. The others with sharp axial ribs, about 
18 on body whorl, narrower than interspaces. These with spiral lines not crossing the ribs. First definitive whorl with 4 lines, next whorls with $5-6$, body whorl with about 16 besides 10 basal ones. Suture concealed by posterior knobs of ribs. Outer lip with thick varix; flattened area behind varix may suppress 4-6 ribs. Inside of outer lip with 3-6 white denticles projecting from a brown longitudinal ribbon not always present. Inner lip with narrow, sharply edged callus, sometimes with longitudinal fold. Aperture oval, simple or constricted by projecting outer lip and parietal shield.

Shell light or darker brown with quite light apex. Suture accompanied in front by white line. Colour pattern variable. Sometimes two more or less distinct darker brown spiral bands on body whorl, the posterior of which continues on to spire. In some shells the bands substituted by crescent-shaped spots prolonged into undulate lines.

Siphon and all soft parts white; mantle under shell pigmented; operculum pumpkinseed-shaped, light yellow.

\section{Discussion of Anachis obesa}

Lange de Morretes (1949, p. 96) records A. ostreicola as separate species. Melvill (1881, p. 160) described it sketchy, Sowerby (1882, p. 119, pl. 5, f. 10) completely. The typical locality is northwest Florida. It belongs to obesa (Dall 1889, p. 188; Kobelt 1897, p. 140) as a dark colour-form. Light and dark shells of our material are linked by such of intermediate shades. Therefore we think that the darkest shells do not deserve a special name, as little as other varieties without restricted geographic range (Pace 1902b, p. 39).

Nassa isabellei d'Orbigny (1841, p. 433; 1846, pl. 61, f. 18-21) fi'om Santos to Argentina, Gulf of San Matias (Carcelles 1944, p. 253 ) is probably identical with obesa. Both have white bodies. The size of the shell in the type of isabellei agrees with obesa; southern isabellei are bigger. The question can be decided only with material from Argentina.

Distribution: Virginia to Florida; the Gulf States and the West Indies (Abbott 1955, p. 221); Brazil, Ubatuba and Itanhaen (present riaterial), Island of São Sebastião (as ostreicola; Lange), coast of Paraná and Sta. Catharina (Lange). 


\section{Anachis veleda (Duclos, 1846) (Fig. 3)}

Length up to $18 \mathrm{~mm}$, breadth up to $8 \mathrm{~mm}$; no shells smaller than $7 \mathrm{~mm}$ were seen. Adult shells thick-walled: young ones thin . Whorls $10-11,21 / 2$ of them nuclear, smooth. All whorls little convcx, but suture somewhat impressed. About 17 axial ribs on body whorl, narrower on other whorls; all ending in front of suture and narrower than interspaces. These smooth; spiral lines only in anterior lialf of body whorl. In young shells the ribs of each whorl with 4 spiral Iuws os beads. Similar knobs at base of shell on crossings of spiral lines with axial ribs. Aperture elliptical or narrowed posteriorly. In old shells allusive varix on outer lip marked by posterior flattening, and slight white callus on inner lip. Inside of outer lip with about 6 denticles; pillar without denticles.

Shell whitish with light or greenish protoconch; distinct white band in front of suture and a second farther in front. Interspaces between ribs darker. Between white bands on ribs of body whorl an anterior and a posterior row of blackish brown dashes; on other whorls only posterior row visible. Anterior spirals with brown spots.

Siphon white with 2-3 black bands, tentacles white with 2 black rings, upper side of foot spotted with brown, around the margin black; sole lighter. In some cases the hind end of the sole was white, evidently due to recent regeneration. Mantle under shell pigmented. Operculum brown, longish, more pointed than that of sparsa.

\section{Discussion of Anachis veleda}

Though Duclos' species was only figured, not described, we use its name which v. Martens (1897, p. 171) applied to Brazilian shells. His drawings (pl. 16, f. 8, 9) and the copy of Duclos' figure (Kobelt 1897 , pl. 43 , f. 18) agree well with our material.

Possibly Lange de Morretes' (1949, p. 96) A. lyrata Sowerby, from the coast of Ceará to Paraná, refers to the same species. $A$. lyrata is Pacific (Kobelt 1897, p. 58-59). The corresponding western Atlantic (Keen 1958, p. 382) A. terpsichore Sowerby, 1822 which Lange (1. c.) records from Bahia, may be our species too. Duclos' 
and v. Martens' figures of veleda however agree better which our material than Kobelt's of terpsichore (1897, pl. 8, f. 5-7) .

Kobelt (p. 40-41, 321) follows Tryon and considers veleda as a variety of $A$. varia (Sowerby, 1832) from the Pacific coast of Mexico, Sonora, to Panama, and A. Myra Keen (1958, p. 386) gives it as a mere synonym of varia. Though that species is a little bigger than veleda, it has less ribs on the body whorl, and its colour pattern (Kobelt, pl. 5, f. 8-14) differs from that of Duclos', v. Martens' and our veleda.

Our material is the shell that is called "felicidade" (happiness) on the beach of São Paulo, where it is collected for ornamental purposes.

Distribution: Brazil: ? Bahia (Lange, terpsichore), Ubatuba (present material), Desterro (to-day Florianopolis), Sta. Catharina (v. Martens); probably also Lange's localities on the coasts of Ceará, Bahia, São Paulo, and Paraná that refer to lyrata.

\section{Nitidella dichroa (Sowerby, 1844) (Fig. 4)}

Length 7 , rarely $8 \mathrm{~mm}$, breadth up to $3 \mathrm{~mm}$; the smallest shells were $1 \mathrm{~mm}$ long. Whorls $6-8$, the 3 of the protoconch flat. Shell smooth and of nearly straight sides, when dry, mat on outer, glossy cn inner side. Suture shallow, spiral lines only on anterior third of body whorl. Aperture narrow, about $2 / 3$ of the length of body whorl. Outer lip with 3-8 denticles in shells thickened by age, columellar lip not denticulated, sometimes with glossy brown callus contrasting with white pillar farther inwards.

Whorls of protoconch without spots, quite dark, the forward whorls with superficial black or dark chestnut brown pigment and highly variable white pattern. An opaque white line in front of suture generally appears as row of dots interrupted by black or is nearly completely concealed. More or less densely disposed round spots, especially on spiral lines around anterior canal and first definitive whorl; other parts with spots and several axial blotches of irrcgular outlines.

Siphon and tentacles black with 2-3 white rings or white with black spots. Proboscis black with white tip and ventral line. Foot 
black with narrow white line at anterior border. Mantle under shell light. Operculum short oval, quite light yellow.

\section{Discussion of Nitidella dichroa}

In the beginning we took our snails for small specimens of the typically 10-14 mm long Nitidella ocellata (Gmelin, 1791). Lange's catalogue does not contain ocellata nor its synonym cribraria (Lamarck, 182.2). Therefore we compared parvula (Dunker, 1847) and moleculina (Ducios, 1846), both indicated by Lange from the northeastern coast of São Paulo, with our material. Kobelt (1897, p. 86-87) identified parvula with ocellata; Johnson (1934, p. 120) maintained it separate, and parvula is really considerably smaller. Its colour pattern consists of blotches (Philippi 1851, pl. 2, f. 7). Also moleculina indicated from deeper water of Northern Argentina by Dall (1889, p. 186) is, according to Kobelt's copy (1897, pl. 40, f. 7) of Duclos' figure, smaller than ocellata and its pattern is rather dots than blotches. We leave the definition of parvula and moleculina to the conchologists with ample collections and bibliography.

Our material must be classified as $N$. dichroa, according to text and figure of Warmke \& Abbott (1961, p. 112, pl. 20 k). Colour pattern and size distinguish it from ocellata. Nearly all our shells collected alive have an entire spire with protoconch, while the apex of adult shells of ocellata is generally decollated (Kobelt 1897, p. 86; Lamy 1941, p. 306, note 2; Abbott 1955, pl. 25 hh; Coomans 1958, pl. 14; A. Myra Keen 1958, f. 484). Besides the occurrence of dichroa near Ubatuba we know it also from the Bay of Santos.

Distribution: West Indies; Brazil, coast of São Paulo, Ubatuba (present material).

\section{Mitrella lunata (Say, 1826)}

Length 3-4 mm, breadth $1,7-1,8 \mathrm{~mm}$; the youngest shell $1 \mathrm{~mm}$. Whorls $5-7$, the 3 of the protoconch convex and with deep suture, the others flatter with not impressed suture. Shell smooth, of variable thickness, in adults rather thick, mat on outer, glossy on inner side. Spiral lines only around siphonal canal. Aperture constricted 
by projecting outer lip. Inside of outer lip with $2-9$, frequently 7 , denticles of somewhat different size, often the 2 nd from behind biggest. Sometimes a varix-like thickening on outer lip and flattening bchind it. Inner lip with narrow callus bearing longitudinal fold, without denticles.

Dark brown line along callus continued around whole aperture. First nuclear whorl generally brown, rarely light, following whorls lighter than definitive ones. These are light olive with white band in front of suture, sometimes concealed, sometimes dissolved into a row of dots. On the band brown crescents from which 1-3 wavy lines run forwards which may anastomose. Occasionally very dark shells eccur .

Siphon white with some black spots, tentacles white with black ring, proboscis white. Back of foot white with thin black meshes, solewhite. Mantle under shell dark grey. Operculum broad oval, colourless.

Present shells frequently attacked by boring ctenostomatous Bryozoa .

\section{Discussion of Mitrella lunata}

Our shells do not show the fine axial stripes described by Kobelt (1897, p. 145), hence agree with Abbott's (1955) and Warmke \& Abbott's (1961) indication "smooth".

Distribution: Massachusetts to Florida, Texas and the West Indies (Abbott 1955, p. 223); Brazil: São Paulo, Ubatuba (present material), Island of São Sebastião (Lange de Morretes 1949, p. 97); coast of Paraná (Gofferjé 1950, p. 243), not common.

\section{Columbella mercatoria (Linné, 1857) (Fig. 5)}

Length of 50 present shells up to $20 \mathrm{~mm}$, breadth $11 \mathrm{~mm}$. Up. to 8 convex whorls, 3 of which belong to the whitish or yellowish protoconch, whose uppermost one, the shell of the veliger, is very large. Eody whorl more than half the height; spire low, acuminate. Sutures. distinct. Growth lines appear in the periostracum; no axial ribs. Distinct revolving ridges on the whole surface, sometimes those on 
base of body whorl a little higher. Aperture narrow, $13 \mathrm{~mm}$ high, as long as body whorl. Outer lip thickened, its inner margin with central convexity and crenulation extended from basal end to a point below anal angle, comprising up to 14 white crenations with more or less distinct mauve-brown marks between them. Inner lip with 4-7 small beads. Columella curved, with thickening divided by a furrow .

Periostracum thick whitish, very fibrous, firmly adherent. Ground colour whitish, maculated, banded or reticulated with black or brown, sometimes colour nearly uniformly brown. Inner side of shell white u. purple. Siphon black on outside, white on inside; tentacles black with white tips; proboscis orange, containing haemoglobin. Foot with black dorsum, white anterior stripe, and reddish-brown sole; roulding gland white. Mantle under shell white or pigmented. Pericardium white due to filling with sperm; kidney purplish; stomach green; digestive gland olive; intestine greyish green. Ovocytes in ovary olive; capsule gland white.

Operculum small, thin, nearly triangular, light yellow, with terminal nucleus and conchinous ridge in middle of thin area, where muscle inserts. Absence of pigment at hind tip of foot and comparison with present complete operculum of rustica suggest that all present opercula of mercatoria were in regeneration.

\section{Discussion of Columbella mercatoria}

The mauve-brown marks between the crenulations (Abbott 1955, p. 220: rusticoides), the very fibrous periostracum (Perry \& Schwengel 1955, p. 160: "hispid epidermis" of rusticoides), and the geographic indications for Brazil (Lange de Morretes 1949, p. 95-96) riade us doubt how to call our material, till we saw Warmke \& Abbott's figure (1961, pl. 20 a). C. rusticoides is up to $28 \mathrm{~mm}$ long, smooth on the centre of the body whorl, and slender, not squat as our snails. This becomes evident by the proportion of length and bieadth (1) of the shells: rusticoides (Heilprin 1887, pl. 8, f. 9) 2,0; iusticoides (Perry \& Schwengel, f. 223) 2,05; mercatoria (Abbott 1955, pl. 25 bb) 1,68; mercatoria (Warmke \& Abbott 1961, pl. 20 a) 1,67 ; present material (10 shells measured) 1,67; mercatoria (Coomans 1958, pl. 14) 1,51 (spire worn). 
The name of the genus refers to the comparison of the Dove-shell c. mercatoria to a breeding dove, whose apex is the head, and the outer lip the lowered left wing. The translation "pretty column" (Perry \& Schwengel, note 295$)$ is untenable, as are others $(294,296)$. Nitidula is the diminutive form of nitida, while nitedula, the dormouse (Muscardinus avellanarius) alludes to the verb "nitor" (I climb). In contrast to the commercial mercatoria sold for ornamental purposes, rustica is simpler, more rustic, and rusticoides is similar to rustica.

\section{Columbella rustica (Linné, 1758) (Fig. 6)}

The available nine shells are up to $24 \mathrm{~mm}$ long, 12 broad. A total of 8 whorls, 3 of which belong to the brownish or whitish protoconch. Body whorl considerably more than half the height, e. g. $12,5 \mathrm{~mm}$ in a $16,5 \mathrm{~mm}$ long shell. Whorls less convex than in mercatoria, but sutures also distinct. Spire short, pointed. Growth lines as in mercatoria; no ribs. Spiral lines slight, stronger at base. Aperture as long as body whorl, narrow. Outer lip sometimes thick, with central convexity and up to 14 crenations of inner margin, sometimes thin, smooth, without crenulation. When the outer lip is thick, it has a varix and a flattening behind it. Up to 4 beads on the inner lip and a thickening of the columella divided by a furrow occur in shells whose outer lip is thickened, not in the others.

Periostracum thick. Ground colour whitish, also on inside. Black or dark brown colour marks leave more or less transverse white spots free on surface. Foot with sometimes light sometimes dark sole, the sides are spotted and dark below; the anterior border is light. Also the colour of the siphon varies: it may be hardly pigmented, maculated, or nearly black. Proboscis white. Tentacles spotted to nearly black with white tips. Mantle white or black with white border. Operculum almost black; $7 \mathrm{~mm}$ long, $3,5 \mathrm{~mm}$ broad; nucleus apical, at the pointed end. Of the 9 present snails all but one had regenerating hind ends with incomplete opercula.

\section{Discussion of Columbella rustica}

The great variability of the shell with regard to shape and colour is shown by Kobelt's 14 figures (1897, p. 6, pl. 1). The preceding 
description refers only to material preserved in Bouin's liquid at the Zoological Station of Naples.

The range of rustica comprises the Mediterranean Sea, the warm t -mperate Eastern and the Middle Atlantic Ocean, where it extends southwards to the Gulf of Guinea.

\section{GENERAL REMARKS ON THE SHELLS}

The beads or denticles on the inside of the outer lip are taxonomically of little use, because their occurrence is quite irregular. When the outer lip is growing fast and therefore thin, the beads are absent; if growth is slow and the lip thickens, they are developed. The same holds for the callus of the inner lip. The character used in Keen's key (1958, p. 378) for the genera "outer lip smooth in the adults" opposed to "outer lip with teeth in the adult" cannot be applied to the species we have seen.

Already Pace (1902b, p. 39) mentioned that simple, thickened, or denticulate lips are individual, not specific characters. He also denied the systematic significance of shell-size and shape, long and narrow, or short and stumpy, almost globose. According to Pace even the sculpture is subjected to a wide variability. One and the same species may have a longitudinally ribbed, transversely striped, or smooth shell. If this was true, $A$. brasiliana would be a synonym of $A$. avara. However, we do not feel authorized to apply Pace's criteria. They contrast whith the conchological tradition exemplified in A. Myra Keen's key to the genera of Columbellidae (1958, p. 378). We agree with Pace (p. 40) in the diagnostic value of the colour plan from which patterns, often very diverse in a great number of conspecific specimens, can be derived.

The apical angles in our species are: brasiliana $40^{\circ}$, sparsa $40-50^{\circ}$, obesa $55^{\circ}$, veleda $50^{\circ}$, dichroa $40^{\circ}$, lunata $50^{\circ}$, mercatoria, $60-70^{\circ}$, and rustica $66^{\circ}$. Thence a narrow mantle cavity can be inferred for the first six species.

\section{HEAD AND FOOT}

The head is small, without snout, only developed as a salient common socket of the short, pointed, and divergent tentacles. Late- 
rally and basally the tentacles contain the eyes, whose structure corresponds to the Murex-type (Hesse 1934, fig. 58, C). The inconspicuous opening of the proboscis sheath lies beneath the base of the tentacles .

The siphon (Figs. 9, 22, so) is about half the length of the foot and open on its ventral side without curling one border over the other. The ciliated edges to the sides of the ventral slit are straight. Blue-staining subepithelial glands open principally on the inner surface whose epithelium is flat. The siphonal musculature is chiefly longitudinal with sparse radial fibres. The muscle layer is thicker on the ventral than on the dorsal side. As the fibres of the retractor insert on the left dorsal side, the musculature of the corresponding right side is especially weak. The inner and outer muscle layers are separated by a thin stratum of connective tissue containing the siphonal nerves, up to 20 near the tip. Blood lacunae occur between the outer muscles and the epidermis whose cells are higher than those of the inner epithelium.

The left border of the siphon is continued into a massive retractor lodging the siphonal ganglion. This retractor (Fig. 8, ms) accompanies the broad columellar muscle (Fig. 33, c) to the columella. The right border of the siphon is extended inwards into a high, ciliated fold whose loose conective tissue contains blood spaces and subepithelial glands. This fold broadens behind and ends with a small flap in front of the gill.

On the right side of the head the pallial suture forms an acute angle jutting as a minute flap. The columellar muscle originates near the apical suture of the penultimate whorl.

The foot is narrow, truncate in front, without mentum, and printed behind. An operculum is present in all our species, while it is absent in two small species of Risbec's columbellids (1954, p. 132). The operculum (Fig. 7, oc) lies obliquely on a pad (za) set off from the back of the foot and stands out over its sides. The thickly ciliated sole (Fig. 8, sc) is separated from the sides by a longitudinal furrow (mr) which runs from the fore end of the foot to the hind point.

The sole glands (Fig. 8, iv) (Graham 1957, p. 141) lie in the connective tissue under the epithelium of the entire sole and attain 
the furrow. The anterior pedal mucus glands (1. c.) discharge into the deep ciliated groove (Fig. 7, an) that runs across the anterior end of the foot, and into an about $0,1 \mathrm{~mm}$ long canal coursing from the middle of the groove backwards. In dichroa the glands of the groove are, in part, red-staining. A small median invagination or folded pouch (vn) of the ciliated epithelium in front of the middle of the sole is the ventral pedal gland (l. c., p. 142). It contains few gland cells and is only quantitatively less developed in males. The same was found in Lintricula auricularia (Marcus 1959, p. 115). In sparsa the sexual difference of the ventral pedal gland is slight, in dichroa this gland is much more conspicuous in females where it is macroscopically recognizable as a white pit in the black sole. Also the ventral pedal gland of brasiliana and veleda (Fig. 7, vn) can be seen in the living female. It is, however not very distinct, so that the root of the penis showing when the mantle border is lifted in a snail taken out of its shell is the best character to distinguish the sexes.

At the hind tip of the foot, under the operculum, or under its anterior border (obesa) opens the posterior pedal gland (Fig. 8, uo) of Graham's terminology (1957, p. 142). Its round, ciliated and straight canal (ow) attains the region of the nervous system (ea, eu) and contains stretches with mucus glands. The inner end of the canal receives the ducts of numerous mucus glands that lie around the nerve ring, the statocysts, and part of the salivary glands. In veleda and lunata examined in this respect the pedal mucus glands on the right side of the brain are several times as voluminous as the rudimentary ones on the left side. As in Cerithiopsis tubercularis the posterior pedal gland of the columbellids produces the "viscid climbing rope which allows the snail to lower itself from its inverted swimming position on the surface film, or to climb along it with its narrow sole, or it may be used to secure the animal" (Fretter 1951, p. 569). Rissoa membranacea (Johansson 1939, p. 298), Skeneopsis planorbis (Fretter 1948, p. 599), Omalogyrus atomus (ibid., p. 608), Rissoella diaphana, R. opalina (ibid., p. 618, 624), and Cingulopsis fulgida (Fretter \& Patil 1958, p. 115-116) are examples of similar posterior pedal glands in small, "spinning" prosobranchs, but 
those of the mentioned Rissoacea and Cerithiacea have branched canals and open farther in front; the secretion is conveyed to the posterior tip of the foot in a groove of the sole.

\section{LOCOMOTION}

A few preliminary observations were made on locomotion of species 1-6. As other small snails (Ankel 1936, p. 82) the columbellids have the ability to glide on the surface film. We saw it principally in dichroa and lunata. Also the other species, e. g., brasiliana and sparsa "spin" a thread of mucus which is attached to the seaweed or the surface film, and the snail then "dangles and swings on its elastic support" (Myra Keen 1958, p. 378). Rhythmical locomotion, an even gliding on a substratum by undulations of the sole, occurs in all species, but also arhythmical locomotion, gliding alternating with jerks (Weber 1924, p. 112). The foot maintains its contact with the substratum and advances in front of the shell. Then the latter is drawn forwards by contraction of the columellar muscle. This type of locomotion is more frequent in veleda and brasiliana than in dichroa and lunata. Species with bigger, heavier shells and relatively shorter foot move arhythmically oftener than those with smaller shells and relatively longer foot (ibid., p. 120). As the foot is narrow in these species, one can compare the proportion of length of shell and foot in our extreme species. In the following proportions 1 is the length of the foot. We obtained for veleda 1,64-2,0: 1 , and for lunata $0,8-1,17$ : 1 .

Weber (1924, p. 113) derived the arhythmical locomotion from digging. In his example, Conus, this is conceivable, but not so easily in Buccinacea. Though some columbellids plow about in tide pools (Myra Keen, 1. c.), they are not so pronounced diggers as, e. g., the Nassariidae.

Mitrella lunata frequently assumes a peculiar attitude. Fixed cnly with the hind end of its foot to the bottom of a watch-glass, as if standing on its tail, it rises and stretches its siphon upwards moving it in all directions.

The highly extensible foot of the columbellids makes it easy for them to recover when they have fallen upside down. As Weber 
(1926, p. 400) observed at Naples, they grasp with the anterior pedal border. This projects from the aperture and searches in all directions, to the right or left side or even over the middle in front of the shell. Where the pedal border finds a hold, it seizes it and turns over.

\section{PALLIAL ORGANS (Figs. 8, 9, 33)}

The inferior mantle border is thinly ciliate, the upper one is strongly innervated and lodges numerous glands. Where the hind border of the mantle is united with that of the roof of the pallial caivity on the right side, in all species the suture is developed as a prominent fleshy ridge, as already figured by Joannis (1834). The roof of the mantle cavity is richly supplied with blood lacunae, hence probably respiratory. In the innermost part of the floor begins a patch of cilia (Fig. 33, x). The pallial communication (Figs. 25-29, ra) of the renal sperm duct, described in the following, opens in this region on the left side. Farther in front the ciliated area divides into two stripes of small cilia. The left one is short and ends at the posterior level of the ctenidium (b). The right stripe continues beyond the mantle cavity for a short extension under the root of the penis. This right stripe evidently affords an efficient exhalant current.

Generally the epithelium is flat in the mantle cavity (Fig. 9), but a conspicuous hypobranchial gland $(y)$ is developed on the right side of the roof behind the area underlain by blood spaces (si). An interruption of the hypobranchial gland by a penial pouch (Fig. 33, eo) in the male will be described in connexion with the reproductive organs. It is absent in mercatoria and rustica. On the left side the narrow ctenidium (b) extends far backwards. On the afferent side is leaflets bear a pad of glandular epithelium.

The osphradium, though shorter than the gill, is large (Fig. 9, os) .In our smallest species, lunata, it is unipinnate. Also Risbec (1954, p. 132-133) found the left leaflets of the osphradium very reduced in size in C. ligula and absent in C. troglodytes. Even in our bigger species the right osphradial leaflets are more numerous and broader than the left ones. The following table refers to average sriails of our eight species. 


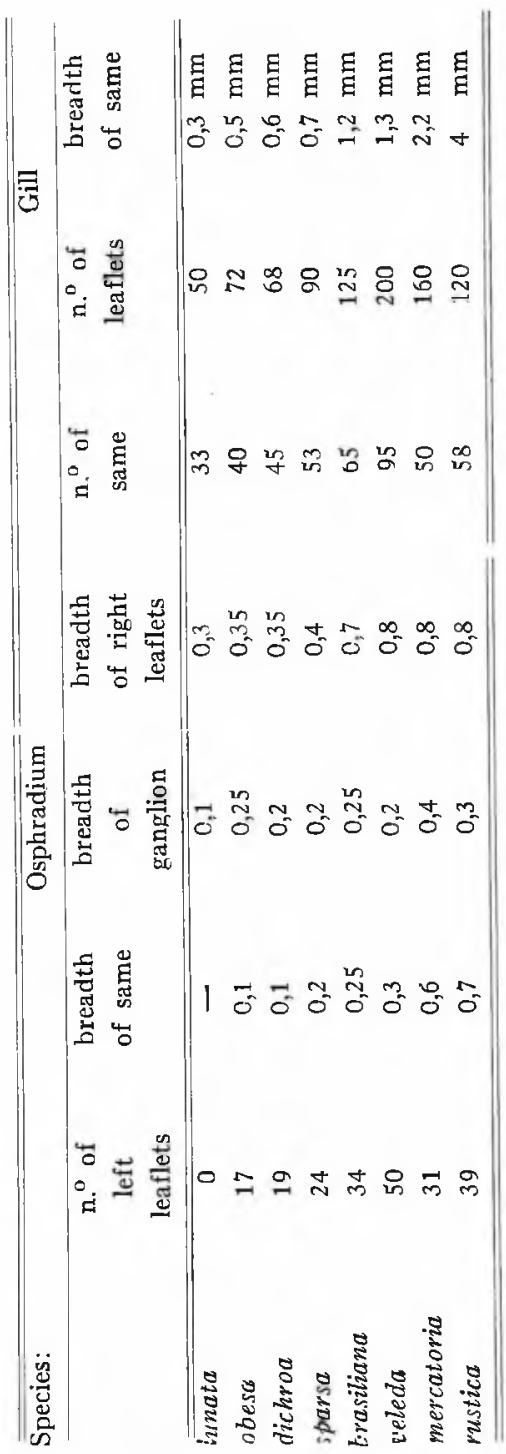


By counting and measuring sections we found that the mass of the central ganglia exceeds that of the osphradial ganglion by $10 \%$.

\section{NERVOUS SYSTEM (Fig. 11)}

The ganglia of the nerve ring lie near together, but are all set off from one another. As in the species examined by Risbec (1954, p. 131) the longish pedal ganglia (ea) are biggest. The right, more dorsal ganglion, which emits the penial nerve (xn), lies farther in front than the left, farther ventral one. A number of pedal nerves leave the anterior margins of the ganglia. These are, as in Risbec's tigure B, 5 (p. 133), subdivided into several cones. One pair of nerves (na) supplies the anterior border of the foot, the others, about 3 pairs (nv), run parallel to the duct of the posterior pedal gland (ow) and branch in the region of the operculum. In dichroa the pedal ganglia are strongly pigmented with black. In mercatoria and rustica the roots of the nerves (na) which supply the anterior border of the foot are separated as conical propodial ganglia by' a furrow fiom the rest of the pedal ganglia.

The cerebral ganglia (er) are almost globular, and the right one is bigger than the left as in Risbec's species. In brasiliana, sparsa, obesa, veleda, dichroa, and lunata the cerebral ganglia lie to the sides of the oesophagus (e), over which their posterior halves are broadly connected without interruption of the layer of nerve cells. In mercatoria and rustica these ganglia are connected by a true supra-oesophageal commissure which is twice as long as broad, hence shorter and broader than that of $C$. versicolor (Risbec, 1954, f. A, 7 ), but essentially comparable. The cerebro-pedal and cerebro-buccal connectives are short, internal connexions in our material. The buccal ganglia (cc) are contiguous without external comissure. They lie between the anterior part of the cerebral ganglia. Much farther ventral are the statocysts (sz) with a single spherical statolith. Their position varies. They lie to the right, sometimes close to the pedal ganglia, sometimes embedded in the racemose salivary glands.

In veleda, mercatoria and rustica, not in our smaller species, each cerebral ganglion has on its anterior and outer side a cap (cz) which consists of small, dark staining nerve cells around a core of 
fibres. Such areae are known from several prosobranchs, also from Buccinum (Hanström 1928, p. 170). In his discussion of the homology of these caps with the procerebrum of pulmonates Hanström (p. 172) ponders their possible relation with the tentacle nerves. In our columbellids these nerves ( $\mathrm{nn}$ ) enter the cerebral ganglia farther dorsally than the caps lie, hence are evidently independent from the caps. The cerebral proboscis nerves unite with those going out from the buccal ganglia and run back to the root of the proboscis.

The pleural ganglia (eu) are of approximately equal size, nearly globular, and delimited against the cerebral ganglia by constrictions. They also touch the pedal ganglia. Yellow pigment occurs in nerve cells of the pleural ganglia as in Olivella verreauxii (Marcus 1959, p. 116). Of the nerves that leave the left pleural ganglion the thickest is the pallial-siphonal nerve ( $\mathrm{sn}$ ). It forms a swelling ( $\mathrm{sw}$ ) covered with nerve cells, hence a peripheral ganglion, at the base of the siphon, and from this secondary centre several branching nerves pass into the siphon. There is a left zygosis (zi) between the pallio-siphonal and the osphradial-branchial nerve (on). From the region where right pleural and subintestinal ganglion are in broad contact, a strong pallio-parietal nerve (wi) arises. It may correspond to the sole nerve which originates from the right pleural ganglion of Buccinum (Bouvier 1887 , p. 268 ), but this comes from the limit between right pleural ganglion and pleuro-pedal connective (Dakin 1912, fig. 6 on p. 69, r.pl.n.) .

Of the short connexions between the pleural ganglia and those at the root of the visceral loop the zygosis between the subintestinal (iu) and the right pleural ganglion is shortest; both these ganglia are fused as in Buccinum (Bouvier 1887, p. 259). Also Risbec (1954, p. 131) stressed this maximum zygoneury on the right side.

Contrary to the position of the supra-intestinal ganglion in Risbec's species (ibid., and f. A, 7, sp) this ganglion (ai) is in ours apposed to the right pleural ganglion. When concentration of the central nervous system is judged, the distance of the supra-intestinal ganglion from the right pleural ganglion must not be overrated; to Thiele's examples (1935, p. 1097) in this connexion two volutids can be added, Adelomelon ancilla (Woodward 1900, p. 11) and Voluta 
musica (Pace 1902a, p. 24). In the former the supra-intestinal ganglion is close to the right pleural ganglion, in the latter it is far away from it and near the osphradium. The visceral cords (vc) pass through the diaphragm between anterior and posterior body cavity, together with the oesophagus and the diverticulum of the gland of Leiblein. Close behind the passage, at the level of the hind end of the gill and in front of the heart, lie the two visceral ganglia (va) apposed to one another. They belong to the supra-oesophageal, left branch of the visceral loop; the subintestinal one contains an accumulation of nerve cells (su) farther in front. The posterior curve of the loop emits a nerve which goes to the genital aperture.

ALIMENTARY TRACT (Figs. 10, 12-21)

The sheath of the proboscis is connected with the dorsal body wall for a certain distance. As in the other Stenoglossa only the part that connects the free hind ends of sheath and proboscis is eversible. When the proboscis (ro) is extended, the sheath encloses its base. The epithelium lining the sheath is flat on the dorsal side and appears higher on the ventral side, perhaps due to contraction. Here, on the floor of the sheath, the transverse layer of muscle fibres is thick. Risbec (1955, p. 71) described this "grande lame musculaire" in his Pacific species.

The pleurembolic proboscis is a little shorter than the shell. Generally it is silky white, orange in mercatoria, and pigmented black with a white tip and ventral line in dichroa. As a very unusual feature a pigmented introvert of Voluta musica was noted by Pace (1902a, v. 22). The high mobility of the very muscular proboscis is evidenced while feeding and by the fact that it can reach every point of the shell and remove sediments which are often swallowed. The two herbivorous species, mercatoria (Fig. 10) and rustica, have a cuticular ring around the anterior opening of the proboscis. This cuticle is dark in mercatoria, colourless in rustica. Evidently by use among the hard algae (mercatoria: Acanthophora spicifera; rustica: possibly also Rhodomelaceae) the ring is irregularly worn, so that nodules separated by gaps are brought about.

The buccal cavity is short, as the radular sac (cs) separates from its hind end close behind the tip of the proboscis, i. e. the 
mouth. Only in veleda the radula ends approximately in the middle of the proboscis, in the other species it is as long as the proboscis (mercatoria, rustica) or projects from its base (remaining species). Radular sac and oesophagus (c) lie in the proboscis as two tubes, each surrounded by its own muscle layer. The tubes are connected with one another by radial and oblique fibres and with the wall of the proboscis by three pairs of longitudinal muscles which insert close to the tip of the proboscis. At the confluence of the radular sac with the buccal cavity the sac forms a ventral pouch (us) into which the foremost oldest and worn teeth of the radula are folded back. The Sálivary ducts (Fig. 12, w) of mercatoria and rustica open into this pouch. In these species radular sac and oesophagus are united only quite in front, at the tip of the proboscis, so that these snails which feed on algae have a more freely movable rasping organ than the others .

The odontophoral cartilages (Fig. 12, rc) are paired behind and, as in Buccinum (Amaudrut, 1898, p. 71), coalesced in front for about $1 \mathrm{~mm}$ of their length in sparsa, for $1,75 \mathrm{~mm}$ in mercatoria. The paired parts are connected by a transverse muscle, conspicuous in mercatoria and rustica, thin in the other species. Each cartilage is formed by a single layer of vesicular cells; mercatoria and rustica have several layers.

The radulae of the examined species are rather uniform. All have a rhachidian plate-like tooth whose posterior border is thickened and smooth. The lateral tooth is movable; it has a pronged cusp and is fixed to the radular membrane only with its base. Right and left cusp may touch over the central tooth or be turned outward. The posterior side of each lateral tooth bears two secondary cusps or "lamellae" (Thiele, 1924, 1931). Shape and size of these cusps as well as their distances from one another are different in the different species (Figs. 13-20). In young lunata with 11-18 micra long lateral teeth the undermost secondary cusp is broad and blunt, really lamella-shaped. As the radulae are not known for all type-species of the genera and subgenera, A. Myra Keen (1958, p. 378-9) arranged the columbellids conchologically. Thiele (1. c.) tried to combine characters of the radulae with those of the shells. This is difficult, e. g. in Nitidella. The spaces between the cusps are not as narrow in dichroa as in the 
type-species nitida (Fischer, 1887, f. 393; Simroth, 1901, f. 122). Also the reproductive organs of dichroa differ widely from those of Thiele's genus Columbella with narrow-spaced lamellae. On the other liand obesa and lunata with wide-spaced lamellae have reproductive organs similar to mercatoria and rustica with narrow-spaced lamellae.

The measurements, in micra, are as follows:

\begin{tabular}{|c|c|c|c|c|}
\hline \multirow[t]{2}{*}{ Species } & \multicolumn{2}{|c|}{ Central tooth } & \multirow{2}{*}{$\begin{array}{l}\text { Breadth of } \\
\text { lateral tooth }\end{array}$} & \multirow{2}{*}{$\begin{array}{c}\text { number of } \\
\text { rows }\end{array}$} \\
\hline & breadth & height & & \\
\hline 1) brasiliana & 38 & 24 & 52 & 215 \\
\hline 2) sbarsa & 40 & 20 & 70 & 100 \\
\hline 3) obesa & 25 & 12 & 28 & 80 \\
\hline 4) veleda & 50 & 31 & 67 & 330 \\
\hline 5) dichroa & 36 & 20 & 50 & 125 \\
\hline 6) lunata & 20 & 15 & 26 & 120 \\
\hline 7) mercatorio & 115 & 31 & 210 & 115 \\
\hline 8) rustica & 140 & 25 & 180 & 100 \\
\hline
\end{tabular}

In the carnivorous species 1-6 a certain proportion between the size of the snails and the number of radular rows can be recognized, but the small lunata is an exception. The herbivores whose higher mobility of the radula and its stronger cartilaginous support were already mentioned have also a radula twice as broad as that of the carnivores, and its plates are thicker.

The clustery salivary glands lie around the central nervous system and the pharynx of Leiblein. In all our species the ducts do not pass through the nerve ring. At first they are ciliate, but lose their cilia in their intra-proboscidial course, except for mercatoria and rustica where they continue ciliated. The long tufts of cilia are developed on either side of the duct on a row of single cells which project on the basal side of the epithelium. In brasiliana, sparsa, obesa, veleda, dichroa, and lunata the ducts run in the lateral folds of the anterior cesophagus which accompany the dorsal food channel. Far in front they pass on both sides through the oesophageal muscles, curve ventrally, enter into the muscle wrapping of the radular sac, and open on both sides into the foremost part of this sac. In mercatoria and rustica the epithelium of the intra-proboscidial oesophagus (Fig. 12, e) 
is thrown into many longitudinal folds behind, and in front is differentiated into lateral folds and dorsal food channel. Behind the salivary ducts run on either side of the ventral midline, in front, in the lateral folds. Right and left duct (w) leave the folds on different levels, and each duct forms a long, unciliate vesicle (a), evidently a salivary ampulla or reservoir beside the oesophagus. As mentioned $b$ fore, the outlets of the reservoirs open separately through the antroro-ventral wall of the radular pouch (us).

The muscles of the anterior oesophagus are connected with those of the wall of the proboscis in the foremost region. Between these muscle layers lie glands which discharge to the outside around the mouth, i. e. the tip of the proboscis. In mercatoria and rustica there are also glands opening into the radular sac and subepithelial oesophageal glands. The part of the oesophagus, that is X-shaped in transverse sections (Fig. 12, e) due to the lateral folds, has a thin, sometimes rough, cuticle, but no cilia. This refers to the entire intra-proboscidial oesophagus of the carnivores and the anterior part in the kerbivores. Cuticle without cilia also lines the posterior intra-proboscidial, folded part of the oesophagus of the herbivores.

Behind the proboscis the epithelium of the oesophagus of the carnivores is thrown into many longitudinal folds, so that the dorsal food channel is no longer recognizable. Hence this part of the anterior cesophagus which curves forwards and then runs transversely has the same aspect in carnivores and herbivores, and is in both cuticularized and ciliate. The oesophagus enters the pyriform pharynx of Leiblein whose greatest extension is dextro-sinistral. Its lumen is not folded, but the entrance of the oesophagus is a regularly folded funnel. The outside of this infundibuliform projection into the pharynx is surrounder! by blue-staining glands and ciliated cells, as the mucous pad in Graham's Stenoglossa (1941, p. 6, 12) and in Oliva (Marcus 1959, p. 125-126). The high epithelium of the pharynx of Leiblein which consists in unciliated gland and slender ciliated cells corresponds to the mentioned snails too. The pharynx of Leiblein of our columbellids is similar in shape to that of the muricids, but does not show the effect of torsion characteristic for this family (Graham 1941, p. 17).

The mid-oesophagus from the pharynx of Leiblein, through the rerve ring, to the entrance of the duct of the gland of Leiblein pre- 
sents a rather regular array of longitudinal folds; the epithelium is ciliated, without cuticle and glands. In this region we tried to identify the strip of unciliated cells that marks the effect of torsion in Buccinum (Graham 1941, f. 5, VC), but did not succeed.

The broad communication between oesophagus and gland of Leiblein is not glandular. As in Risbec's species (1954, p. 130) this communication is differently developed in ours, leaving in 7 of them the anterior end of the gland, in veleda the middle. It is wide in sparsa, narrow in lunata, long in veleda, short in brasiliana and dichroa, and quite short in obesa, mercatoria, and rustica. Even in proportion to the greater size of veleda, mercatoria, and rustica their gland of 1.eiblein is voluminous, in the other species it is small. It is transverse to the main direction of the gut, and its rather flat epithelium whose cells contain some brown pigment is thrown into folds. As in Buccinum (Graham, 1941, p. 17) it is in the columbellids less a secleting gland than in the Muricacea and some Volutacea (Woodward, 1900 , p. 119, 120; Pace, 1902a, p. 23, 28). The gland is elongated irto a tubular canal lined with a simple, flat epithelium as in Buccinum and others (Simroth, 1901, p. 516, pl. 38, f. 5). This canal goes out from the hind end, in one exceptional case of rustica from the middle. It accompanies (Fig. 43, ei) the afferent renal vessel that originates from the cephalic blood sinus and supplies the villosities of the kidney $(\mathrm{k})$. Also in Leucozonia nassa studied by us and in Vasum turbinellum the gland of Leiblein ends within the kidney (Risbec, 1955 , p. 50). Bouvier (1887, p. 278) mentioned the similarity of the long tubular glands of Leiblein ending with a small ampulla in Buccinidae and Fasciolariidae (e. g. Fischer \& Bouvier, 1892 , p. 152 , note 1 , pl. 2 , f. 10 , Le)

The epithelium of the posterior oesophagus (Fig. 21, e) is thrown into numerous longitudinal folds. It is rather high and contains some glands. Brown pigment lies in the apical half of its cells. The folds are irregular, of variable height and length. After its passage from the anterior to the posterior visceral cavity the oesophagus courses first in transverse and then again in longitudinal direction. As the posterior oesophagus dilates gradually into the stomach, its limit against the latter cannot be indicated exactly. However we think that the "entonnoir transparent", the gastric shield (is), does not as 
Risbec indicated (1954, p. 130) lie in the cardia. In dissections the limit between the oesophagus and the stomach appears to be between the brown oesophageal and the white gastric limb of the U-shaped organ.

Thus the stomach would be rather similar to that of Trivia monacha (Graham, 1949, p. 748, f. 20), except for the more numerous and more densely disposed folds of the oesophagus and the sorting area (sa) in the columbellids. The right liver duct (1) opens short behind the entrance of the oesophagus. The gastric shield (is) is free, only fastened to the wall with one short side, as observed by Risbec (1954, p. 130) and well developed in mercatoria and rustica. In the other species it covers a small area, but the thin cuticle around it extends farther. In a concavity between gastric shield and major typhlosole ( $\mathrm{rm})$ particles of food accumulate, rotate, and become agglutinated to a string (oo). The left liver duct (1) opens between the typhlosoles at the beginning of the intestinal groove (ir). The left, ninor, typholosole ( $\mathrm{mi}$ ) reaches almost to the oesophageal opening as in Trivia. The intestine (i) is rather short; an anal gland does not occur.

Oesophagus, stomach, and intestine of rustica contain pieces of algae whose sections are similar to those of Rhodomelaceae. The quantity of algal fragments is so great in several specimens that we fcel justificied to consider brown algae as the principal food of rustica. Also the recognizable contents of the gut of mercatoria are algae. In the alimentary tract of the 6 other species we found polychaetes and their setae, crustacean muscles and tubes which we consider to be abdomina of composite ascidians. We suppose that these were torn off from their pharynges. Enormous balls of sperm several times found can have been engulfed together with the abdomina. Also Trivia feeds on colonial ascidians (Fretter 1951a). In the laboratory specimens of our 6 carnivorous columbellids accepted pieces of lamellibranchs, crustaceans, and fish. We did not keep mercatoria alive yet.

\section{RENAL ORGAN (Fig. 22)}

The kidney $(k)$ is a longish undivided sac situated on the outside of the penultimate whorl, on the left side. It lies on the apical 
border of this whorl. The posterior oesophagus (ma) is apposed to its anterior border but extends a little farther backwards than the kidney. The renal sac lies principally behind the heart, but the urinary chamber (Figs. 42, 43, ui), the foremost part of the nephridium, in front of it. This lobe is situated in the roof of the mantle cavity and opens into the cavity with a slit-like aperture (Figs. 9, 43, ni). The anterior part of the kidney is separated from the rest by the heart. The rcno-pericardial communication (Fig. 43, re) is located where the renopallial opening is nearest to the heart. In most cases this communication is a minute tube, but in mercatoria and rustica it is a well developed, about $0,3 \mathrm{~mm}$ long canal in both sexes. In the females of lunata and obesa is is a wide, long, and strongly ciliated canal. In the description of the female reproductive organs we will return to this peculiarity as well as to the character of the epithelium that surrounds the pallial renal aperture in the females of the mentioned species.

On the whole the wall on the outer side of the kidney is smooth and thin, the inner wall of species 1-6 bears folds (Figs. 22, 43, f) which are a little branched in the bigger species. The folds are high in dorso-ventral, flat in antero-posterior direction. In mercatoria and rustica the folds are richly sub-divided and cover also part of the outer wall. The afferent renal vessel enters the bottom of the kidney from the anterior side and ascends towards the upper hind end. Along its dorsal course this vessel bears one row of villosities (vi) on either side and emits branches into the folds of species 1-6. In the big species, mercatoria and rustica, the villosities are more numerous, and occur also on the outer wall beside the vessel; their cells contain the known red-staining granules (Cuénot, 1914, p. 281). The blood from the folds flows into the afferent branchial vessel, that from the villosities through the small nephridial gland (Fig. 33, oa) into the auricle (au). The spongy tissue of the gland protrudes into the auricle (Fig. 43, oa). Some tubules formed by ciliated renal epithelium penetrate into the spongy tissue.

Nearly on its whole length the afferent renal vessel contains the tubular elongation of the hind end of the gland of Leiblein (Fig. 43, ei) which ends without dilatation . 


\section{MALE REPRODUCTIVE ORGANS (Figs. 23-33)}

The testis lies in the apex as uppermost organ or beside the digestive gland, but unlike in Ocenebra erinacea (Fretter, 1941, p. 174) cn the outer side. The long efferent duct runs coiled on the columellar side. It is unciliate, hence a gonadial or testicular sperm duct. It is distended (sv) by eupyrene sperms with thin heads. In mercatoria (Fig. 23) and rustica (Fig. 24) the latter lie around the dyspyrene (Ankel, 1926, p. 154, note 7) sperms whose pink cylinders were only found within the coiled region of the sperm duct in the two mentioned species. In brasiliana (Fig. 25), sparsa (Fig. 26), dichroa (Fig. 27), and veleda (Fig. 28) the duct opens into a seminal vesicle (rv), absent in the 4 other studied species. In sparsa and dichroa the duct passes along this vesicle and opens into its anterior end; in brasiliana it enters the vesicle near its middle, and in veleda rear its posterior end. The epithelium of the vesicle is quite flat, unciliated, not prostatic. The seminal vesicle lies beneath the fundus of the pallial cavity, between renal aperture and anus. In brasiliana and veleda the vesicle receives the unciliated gonadial, in sparsa and irchroa the ciliated renal sperm duct. The 4 species with seminal vesicle, as well as mercatoria and rustica without it, have atypical sperms. In the first these were found only in the vesicle where eupyrene ones $\therefore$ ie rare, except for veleda. In the long seminal vesicle of this species masses of typical sperms lie near the entrance of the sperm duct, while the atypical ones occupy the fundus.

In the reproductive organs of females dyspyrene sperms were noted only in one doubtful case (brasiliana); as the available females of rustica had not copulated, this species must be left aside for this statement.

Odette Tuzet (1930, p. 160-61, pl. 9, f. 284-85) and others (see her bibliography) described the atypical sperms of Columbella rustica. Three possible functions of these sperms have been considered. The first, transference of eupyrene sperms by dyspyrene ones (Ankel, 1930, r. 540; Graham, 1954), cannot be supposed in the columbellids, all with penis. The second, determination of nurse-eggs by atypical fertilization, is probable in Fasciolaria tulipa (Hyman, 1925) Buccinum undatum (Portmann, 1926, 1927), and Thais lapillus (id., 1930), 
evidently not in Pisania maculosa and Fasciolaria lignaria (Staiger, 1950 , p. 499). The species with atypical sperms whose spawn we have kept alive, brasiliana and sparsa, have no nurse-eggs. The third function of the dyspyrene sperms, to provide nourishment for the eupyrene ones has been suggested by Hanson, Randall and Bayley (1952, p. 77). They generalize the lack of accessory glands in Viviparus for the reproductive system of all male prosobranchs in order to support their hypothesis. Our species brasiliana and veleda without prostate and with dyspyrene sperms as well as lunata and obesa with prostate and without dyspyrene sperms seem to favor the idea of Flanson and his collaborators, but mercatoria and rustica with prostate and with dyspyrene sperms do not.

A spermiducal-pallial communication ( $\mathrm{ra}$ ) belonging to the renal section of the sperm duct occurs in all our species. It is a long, narrow canal in brasiliana (Fig. 25), and sparsa (Fig. 26); a shorter cinal in lunata (Fig. 29), obesa (Fig. 30), and rustica (Fig. 24); a quite short funnel in dichroa (Fig. 27), and short and thin in veleda (Fig. 28). In mercatoria (Fig. 23) it is bigger than in all other species and has a wide opening. In dichroa this connexion lies entally (proximally) to the seminal vesicle, in veleda at its beginring, and in brasiliana and sparsa ectally (distally) to it. A slight gonopericardial strand of connective tissue was noted in dichroa; it goes out from the sperm duct opposite to the spermiducal-pallial communication. In mercatoria the flat-celled pericardium emits a diverticulum whose lining epithelium is higher. This diverticulum nearly attains the sperm duct at the limit of gonadial and renal scetion .

The pallial sperm duct (d) is characterized by a thick muscle layer. In transverse section it is circular, and its narrow lumen is lined with a ciliated epithelium. The duct passes along the mantle cavity underneath the floor to the penis with the same diameter throughout and without prostatic glands in four of our eight species (brasiliana, sparsa, dichroa, veleda). In the others there are prostatic glands (rs), a pair of free ones in lunata (Fig. 31), and a single intercalary gland in obesa (Fig. 32), mercatoria (Fig. 23), and rustica (Fig. 24). 
In lunata the pallial sperm duct becomes thicker at a point where it receives the red-staining coarse granules secreted by the two tubular glands. One of these opens directly into the sperm duct, while the other is connected with it by a long ciliate and muscular canal. The glands are unbranched coiled around one another, and lie beside the other organs of the visceral mass (Fig. 33). Their lining consists of high merocrine cells with basal nuclei and fine ciliated supporting cells with small apical nuclei between them as in Littorina (Linke, 1933, p. 16). Ectally to the entrance of the prostatic glands the epithelium of the sperm duct becomes high and stores granules; the supporting cells between the storing cells are ciliated.

In obesa, mercatoria, and rustica the efferent duct widens suddently and bends backwards. In mercatoria and rustica it forms a single, in obesa a double loop, runs forward again and continues with the same width to the root of the penis. In obesa the epithelium of the widened section is exactly like that of the glands of lunata; in mercatoria and rustica the nuclei of the supporting cells are basal or central, not apical.

The small single gland that opens on the outside of the penis of Columbella flava (Risbec, 1954, p. 132, f. 6, gl) may be prostatic too, but cannot be compared morphologically with the prostates of the 4 precedingly mentioned species. In mercatoria and rustica a great number of blue-staining subepithelial glands open on the tip of the penis around the male opening.

The prostatic gland cells continue along the ejaculatory duct of cibesa, mercatoria and rustica. In the middle part of this duct there are red-staining glands in sparsa, lunata and dichroa. Besides blue-staining glands occur in the terminal part of the ejaculatory duct of sparsa. Some of the high epithelial cells of this duct contain blue-staining granules in rustica. In veleda the epithelium of the penial sperm duct includes pink-staining glands; in brasiliana only the basal part of the duct is glandular. Probably occurrence and colourability of the glands in the ejaculatory duct (Fig. 33, eo) vary according to the reproductive phase. The muscular duct of veleda is sometimes sinuous, that of brasiliana is commonly winding. In the other species it runs more or less straight to the tip where it opens in all our species. 
All have a male copulatory organ which is flattened in resting state. Except in mercatoria and rustica the outer half of the penis lies in a pouch (Figs. 9, 33, eo) which opens about in the middle of the hypobranchial gland $(y)$. The glandular cells are interrupted at the entrance of the pouch, but backwards they fuse over it. In lunata the entrance lies at the limit between ctenidium and hypobranchial gland. The pouch extends backwards maximally to over the kidney, hence far beyond the fundus of the mantle cavity. The pouch is lined with a flat epithelium. This pouch, as far as we know, unique in prosobranchs, seems to be biologically significant for snails whose penis is big also in resting state (Fig. 9, q). If it was tucked into the rather narrow mantle cavity, it might interfere with the respiratory current. The penis lies in the pouch with its tip directed backwards. The two species with a wider pallial cavity, mercatoria and rustica, have no penial pouch; their penis lies bent into the mantle cavity. The projecting male organ of Joannis' figure and text (1834) is evidently in beginning erection. The mantle cavity of the female is free from the swollen penis during copulation in Skeneopsis planorbis (Fretter, 1948, p. 606; 1953, p. 220) whose male organ is inserted between mantle and shell of the female.

In proportion to the length of the shell the preserved resting penes are relatively shortest in our biggest species, mercatoria 0,67:1, and veleda $0,66: 1$. In lunata, our smallest species, the proportion is $0,71: 1$; the penial pouch of this species is short. The other proportions are: brasiliana $0,7.3: 1$; sparsa $0,77: 1$; dichroa $0,86: 1$; and obesa $1: 1$. In rustica the males were evidently not in their reproductive period, as their penes were only 0,38:1. The material was preserved at Naples in September; also the females did not contain sperm in oviduct and annexes. The penis of rustica and mercatoria is broad and flat, that of sparsa broad (Fig. 9, q), that of dichroa has a specially thin middle and terminal part which lie in the pouch. Also in brasiliana these parts are thin, the base is thicker. The penis of all species is white, except that of sparsa whose base is pigmented. In rustica the pigmentation and the length of the penis exhibit variation; the organ is sometimes white, sometimes black. One full-grown male whose pallial and penial sperm duct shone black through the skin had a $1 \mathrm{~mm}$ long, 0,12 mm thick penis, hence a proportion of 0,04:1. 


\section{FEMALE REPRODUCTIVE ORGANS (Figs. 34-43)}

The ovary extends with its lobules between those of the subjacent digestive gland in the uppermost whorls. Thence the straight linciliate oviduct runs forward on the columellar side. In the smaller species ( $n .{ }^{\circ} \mathrm{s}$ 1-6) the epithelium of the incipient oviduct is quite low (ovarian oviduct), whence it becomes a little higher (renal cviduct); in mercatoria and rustica the outer part of the oviduct can with certainty be defined as renal oviduct by high cells of the epithelium and longitudinal folds. Though the efferent female organs are different in all our eight examined species, two main groups are clearly distinguished, one without gonopericardial duct, with albumen gland, and with oviducal sperm-storing organs, and the other with such a duct, without albumen gland, and the pericardium storing sperm. The first group comprises brasiliana (Fig. 34), sparsa (Fig. 35), dichroa (Fig. 36), and veleda (Fig. 37); the second lunata (Fig. 38), obesa (Fig. 40), mercatoria (Fig. 42), and rustica (Fig. 43).

In the first group the lumen of the albumen gland (az) is surrounded by the typcial tubes of reddish-staining gland cells. Also the following part, the capsule gland ( $\mathrm{cn}$ ), corresponds to the general scheme of the Stenoglossa (Fretter 1941). The lateral walls consist of long glandular tubes which stain differently in the different zones of the organ. The central lumen is high in dorso-ventral, narrow in dextro-sinistral extension. The cilia of this lumen are absent on the ventral side which corresponds to the sperm channel (l. c., f. 5, $\mathrm{VC}$ ). In veleda the ventral gutter is set off from the central lumen by two symmetrical folds similar to those in Nassarius reticulatus (1. c., f. 5c); in brasiliana one fold on the columellar side is develuped; in sparsa and dichroa there are no limiting folds.

The capsule gland opens into a ciliate vestibule (v). Except for sparsa the vestibule is strongly muscular. The vestibular lumen is distended into irregular pouches in brasiliana, sparsa, and veleda; in dichroa it is smooth. The outer opening $(u)$ of the vestibule lies close to the anus (ar); it is especially broad in veleda (Fig. 37). In snarsa (Fig. 35) the narrow outlet (xi) of the vestibule (v) runs on 
the columellar side of the anus (ar). It is lined with a flat, not folded epithelium. The connective tissue around this duct up to the outermost region of the vestibule is interwoven with muscle fibres. Evidently this duct functions as nidamental duct, not for the entrance of the copulatory organ. The wide and folded vagina of sparsa is a sccond communication $(u)$ of the mantle cavity with the outer region of the vestibule. It is sparsely ciliated and is functionally continued into the likewise folded canal of the bursa (ur) to be described in the following.

Vestibular appendages which receive sperms during copulation and store them occur in all species of the first group. Morphologically these organs are distal copulatory bursae (ur); proximal sperm reservatories between capsule and albumen gland which are frequent in Stenoglossa do not occur. The bursa is globular or nearly so, except for veleda where it is sausage-shaped (Fig. 37, ur) .

In brasiliana and dichroa the ciliate appendage has a central cavity and peripheral tubules. In brasiliana (Fig. 34) these are numerous and surround the cavity; in dichroa (Fig. 36) they amount te 6-8 and lie around the fundus. The cavity of brasiliana contains eupyrene sperms and possibly dyspyrene ones, though the long cilia of the epithelium make it difficult to distinguish them from the cont $\mathrm{nts}$ of the lumen. The peripheral tubules contain eupyrene sperms only. Possibly the atypical sperms as well as the excess of the typical ones are digested in a phase following that of our sections. In dichroa ingestion of sperm by the lining epithelium of the bursal cavity is distinct in some areae, though the mass of coiled sperms obscures great stretches of this epithelium. The tubules (zs) store sperms whose heads are orientated towards the walls. Thus dichroa has the bursa functionally divided into a sperm-receiving and a sperm-keeping part. As mentioned above, vestibular pouches are absent in cichroa.

In sparsa (Fig. 35) and veleda (Fig. 37) the bursa (ur) has no separate central cavity and peripheral tubules. The folded uncijiate bursal canal of sparsa leads into a thick-walled, broadly ovoid vesicle. The epithelium of this vesicle ingests sperm, and the same holds for veleda. 
The vestibular pouches (zs) store sperms in the species of the group which have these organs, viz. brasiliana, sparsa, and veleda. In r rasiliana we verified that the sperms in these pouches are exclusively of the eupyrene type.

The ciliate gonopericardial duct (no) of the second group (Figs. $38-40,42-43$ ) connects the pericardium (ca) with the oviduct (io) where it enters the capsule gland (in) (lunata, mercatoria) or with the inner part of the capsule gland (obesa, rustica). The duct is muscular in its whole length in lunata; in obesa it widens when it enters the pericardium, and this entrance is marked by a constriction produced by a thin sphincter. The duct of mercatoria and rustica begins thin and coiled on the oviducal side, then becomes folded and strongly muscular, and merges into a diverticulum of the pericardium without limit, except for a slight sphincter in rustica.

In 3 species of the second group the pericardial cavity contains sperm mixed with prostatic secretion. Our females of rustica were mature, but had not copulated. They have, however, the same high and ciliate pericardial epithelium (ca) as the other species, while that of the males is quite flat and unciliated. Red-staining granules were seen in the pericardial epithelium, but no ingestion of sperm. In the females of mercatoria and rustica (Figs. 42-43) the modified pericardial epithelium coats also auricle and ventricle. In mercatoria pericardium and gonopericardial duct appear to have different function. The pericardium contains disorderly sperms (se) and secretion, as in a bursa copulatrix; the duct (no) only oriented sperms, in part attached to the wall, as in a receptaculum seminis. In some scctions this seminal receptacle seems to function as ingesting gland (Fretter, 1941, p. 182, 189, 192).

In 3 species of the second group (obesa, mercatoria, rustica) a gonopericardial-pallial communication $(\mathrm{g})$, morphologically a right ureter, occurs regularly; in lunata exceptionally (Fig. 39). In obesa (Fig. 40) a long and thin tube (g) begins with a sphincter opposite to the pericardial opening of the gonopericardial duct (no). It runs forwards to open into the mantle cavity at the limit between pericardium (ca) and kidney ( $\mathrm{k}$ ). The place of the opening is the same in mercatoria and rustica. It begins in the widened part of the gonopericardial duct, in rustica with a feeble sphincter. In rustica (Fig. 
43) the gonopericardial-pallial communication ( $g$ ) is short and wide, in mercatoria (Fig. 42) longer and thinner.

In lunata (Fig. 38) whose gonopericardial duct (no) is very thin and long one of 10 sectioned females had a pericardial-pallial communication (Fig. 39). This is a narrow, about 50 micra long canal which begins close to the pericardial opening of the gonopericardial duct. It is lined with high cells without the cilia and grannules of the pericardial epithelium (ca) and opens into the mantle cavity $(p)$ as in the other species, between pericardium and kidney.

In lunata and obesa the renopericardial duct and the renal aperture are different in females and males. The duct of the female is a wide, densely ciliated canal (Figs. $38,40,41$, re), that of the male inconspicuous. The epithelium of the mantle cavity around the renal aperture (ni) is composed of high and narrow gland cells containing biue-staining droplets. Possibly the secretion of these glands has one of the functions attributed to those of the female aperture of the right ureter in Trochacea (Fretter 1946, p. 334), viz. making the discharge of the egg capsules from the mantle cavity easier, or adding some substance to them. In the males the pallial epithelium is a little richer in cells around the renal aperture than farther outwards, but does not include gland cells. In mercatoria and rustica the sexes do not differ with regard to the renopericardial duct and the epithelium around the renal aperture.

As mentioned above, the pallial oviduct of the second group is represented only by the capsule gland (cn). The unciliated ventral channel of this organ is not limited against the central lumen by folds in all 4 species. In lunata and obesa some sperms were seen high up in this channel near the gonopericardial duct. The capsule gland discharges into a muscular vestibule (Figs. 38, 40, v). This opens (u) into the mantle cavity between hypobranchial gland and rectum (ar). In mercatoria and rustica the vestibule (Figs. 42, 43, v) is short and folded, not specially muscular.

EGGS AND LARVAE (Figs. 44-52)

On the Sargassum where the adult snails live we found egg capsules of two species. They are similar to those of Anachis iontha 
(Ravenel, 1861) (Perry and Schwengel 1955, pl. 50, f. 344). One kind was determined as laid by brasiliana (Fig. 45) by the capsules fastened to the panes of an aquarium in which only brasiliana was present. We attribute the second type (Fig. 44) to sparsa due to the comparison of the shell of the hatching veligers (Figs. 51, 52) with the protoconch of the adult snails. Already Pace (1902b, p. 40) emphasized the diagnostic value of the protoconch for distinguishing the adult shells specifically. In both species the adhesion disc of the egg capsule is polygonal. In sparsa it is 1,1-1,2 mm long, $0,6 \mathrm{~mm}$ broad; in brasiliana $0,8 \mathrm{~mm}$ in diameter. From this disc rise the walls of the capsule. This is flask-shaped and about $0,5 \mathrm{~mm}$ high in brasiliana, like an obtuse cone and $0,7 \mathrm{~mm}$ high in sparsa. In the latter about 20 fine irregularly spaced ridges support the wall which ends with a projecting edge around the flat, $0,6 \mathrm{~mm}$ long, $0,4 \mathrm{~mm}$ broad top closed by a membrane. In brasiliana a collar expands from the circular top whose lid bears a cruciform fold. The collar is 0,6 $\mathrm{mm}$ in diameter and stiffened by about 10 ribs, in part continued down the side walls. The species studied by Perry and Schwengel (1. c.) and Columbella blanda (Thorson 1940, p. 206) have a similar collar around the top of the capsule, but without ribs. The capsules of brasiliana and sparsa are so transparent that the eggs are visible through the walls.

The developmental stage of the embryos makes it possible to estimate the number of egg capsules laid at one time with 10-20. We found, it is true, 37 (sparsa), 49 (brasiliana) and even 64 (brasiliana) capsules in one patch, but they contained embryos of different ages (Fig. 46), hence had been laid at different times or by several females. The number of eggs in each capsule is about 10 in brasiliana and about 20 in sparsa.

The single spawn of veleda mentioned in the introductory chapter produced in a dish (Fig. 49) made it possible to identify 18 empty capsules of this species (Fig. 48) found on one leaf of Sargassum. The capsules are shaped like upside down mugs with concentric ridges; the one laid in the dish contained 30 eggs, $0,2 \mathrm{~mm}$ in diameter.

As is also shown in the figure of the egg capsules of Anachis iontha (1. c.), the newly laid eggs, $0,14 \mathrm{~mm}$ (brasiliana) and 0,18 $\mathrm{mm}$ (sparsa) in diameter, do not fill the inner space of the capsule. 
During its development the embryo distends and forms inner cavities, and so its size increases. As in Anachis avara semiplicata (Perry and Schwengel 1955, p. 159) also in brasiliana and sparsa the number of laid eggs and hatching veligers remains the same. In several other columbellids of the intertidal zone in warm waters the embryos in the capsule feed on nurse-eggs (Petit et Risbec 1929, p. 568; Thorson 1940, p. 206-207).

At about $23-25^{\circ} \mathrm{C}$. the veligers of sparsa and brasiliana hatch within 10-12 days. They have two velar lobes (Fig. 50), the right of which is bigger. The same holds for the veliger of the Mitrella-spec. drawn by Habe (1944, p. 189, f. 5), but this veliger has two tentacles, while ours hatch with one. Two eyes with lenses, and a big pedal gland are already developed. The shell has one and a half whorl, while the protoconch of the adult shell has 3-4 whorls. Therefore it is probable that these veligers live pelagically for a certain time, developing not only one to two and a half whorls more, but possibly also two more velar lobes. In the pelagic veliger of Columbella costulata (haliaëti) whose shell consists of 3 whorls, there are 4 velar lobes (Pelseneer 1906, p. 140).

Some preliminary observations refer to egg capsules of obesa and lunata, found in sectioned capsule glands. In the latter the capsule is $0,16 \mathrm{~mm}$ long, $0,1 \mathrm{~mm}$ broad, and $0.08 \mathrm{~mm}$ high. In obesa the corresponding measurements are $0,2 \mathrm{~mm}, 0,13 \mathrm{~mm}$, and $0,1 \mathrm{~mm}$. The capsule of obesa has somewhat irregular slightly shrunken walls. The measurements of full grown ovocytes in the ovary and those of the contents of the capsule suggest that only one egg is enclosed in the capsules of obesa and lunata.

\section{PARASITES}

Algae, small oysters, serpulids, and Bryozoa, principally incrusting Malacostega, as Membraniporidae and allied families, grow on the shells of all our species. Boring Ctenostomata of the family Immergentiidae Silén (1946, p. 6) bore in the shells. In July 1960 24 of 82 counted living brasiliana had their shells inhabited by thes Erryozoa. We found them in all our Brazilian columbellids excep whesa; this may be due to the relative rarity of this species. 
One C. rustica from Naples had polychaetes, probably of the genus Polydora, in its shell whose calcification was thickened around the worms.

A polyclad flatw.sm, Hoploplana usaguia Edmund H. Smith (1960) occurs in the mantle cavity of many of our columbellids, in the buccinids Cantharus auritula Link and Pisania janeirensis Philippi, and the fasciolariid Leucozonia nassa (Gmelin). All worms found in the columbellids were much smaller than those from the larger snails, viz. up to $1,5 \mathrm{~mm}$ in length, and immature, or in the first, the male, sexual phase. We have found the following, female, phase only in bigger worms from Cantharus, Pisania, and Leucozonia. As was seen in sections, the polyclads lay with their dorsal side against the ctenidium, and the pharynx towards the mantle cavity, whose current produced by the branchial cilia brings micro-organisms into the pallial cavity. Here they are stuck together with mucus, so that the polyclad profits of protection, current water, and food.

During the periods while we studied the life of our columbellids, in July 1960 and December 1960-January 1961 the digestive gland of brasiliana was infested with sporocysts and cercariae whose tails are much longer than those of Cercaria columbellae Pagenstecher (1863, p. 306) discovered in Columbella rustica at Spezia (Italy). Pagenstecher defined the larval sacs as rediae. Arvy (1952) who thinks that the larval sacs and short-tailed cercariae he found in $C$. rustica at Villefranche (France) belong to Cercaria columbellae, calls the sacs sporocysts in his and Pagenstecher's material. In ours the nature of the larval sacs as sporocysts was verified in sections. Stomach and digestive gland of our mercatoria contained larvae of another trematode in November 1960. The cercariae were long, slender, and had big eyes, while those from brasiliana were eyeless. The definitive hosts of the flukes whose larvae live in columbellids must be fishes, which are known to feed on these snails (Nobre 1938-40, p. 199).

A living tetraphyllid plerocercoid was once found free, not encysted, in the stomach of an Anachis veleda, in December 1960. Probably it has reached the snail with its first host, a copepod (see Reichenbach-Klinke, 1956). 
Females of parasitic copepods belonging to the Lernaeopodoida cccur in brasiliana and sparsa. In winter and summer 1960, 5-10\% of the examined snails bore these parasites, and up to 4 of them were found in one snail. The crustacean lives embedded in the tissue behind the mantle cavity of the host, and the two cylindrical sacs with the multiseriate eggs hang into the pallial cavity.

Small white axially and spirally sculptured pyramidellids, similar to certain Odostomia (Abbott 1955, text-fig. 62, a, j), were found crawling on shells of living Mitrella lunata, and once a snail sitting on a lunata with its proboscis widely everted sucked at the foot of the columbellid. According to Robertson (1957) his finding of Odostomia (Chrysallida) seminuda (C. B. Adams) on Crepicula fornicata (Linné) at Woods Hole was the first observation of a gastropod host of pyramidellids; Ankel (1959, p. 13-17) mentioned further cases.

\section{CONCLUSIONS}

The shell of many columbellids is bucciniform. Nevertheless Eouvier (1887) did not consider them in his "Tableau résumant" of classification, probably because the nervous system was not known at that time. In the text (p. 472) the columbellids are placed in Troschel's Rhachiglossa, according to the radula. This position is maintained by Fischer (1887, p. 597) and is consonant with that of to-day. Thiele who studied the radula of many species (1924) allocated the Columbellidae to his superfamily ("stirps") Buccinacea (1925). Evidently Bouvier (1887, p. 247) and Thiele (1935, p. 1039) were quite right to consider the radula as an excellent character for the definition of natural groups in the prosobranchs, not as overrated (Pace, 1902a, p. 24-25). As Bouvier stressed (1. c., and p. 463), aberrant radulae should not be used to assemble snails with no other similarities. The radulae of the Columbellidae, however, are not aberrant. They are sufficiently peculiar to characterize them as a family of the Buccinacea. This refers less to the median tooth than to the lateral plates. Rhachidian teeth without cusp occur also in the Buccinidae, e. g. in Liomesus and Beringius, and exceptionally in Cantharus (Cooke, 1895. f. 123). 
The lateral teeth of the columbellids are versatile plates which may be turned inwards and outwards. They correspond functionnally, not morphologically, to those of Olivella, whose accessory plates or rectangular bases (Marcus, 1959, p. 121) articulate with the lateral teeth. In the first figure of the radula of Pseudanachis duclosiana Thiele $(1924$, pl. 9, f. 7 b) gave a columbellidan base of the lateral tooth, but did not in the second one $(1931$, f. 337), so that the sys$t \in$ matic position of this genus becomes somewhat doubtful. Rhachidian plates with multidentate cusp as in Pseudanachis occur also in the Buccinidae Macron and Clea (ibid., f. 352, 354) and in several nassariids (e. g., f. 373).

Excepting the genera Pseudanachis and Pseudamycla whose radulae are not columbellidan, this organ does not diverge widely within the Columbellidae. Already Pace (1902b, p. 40) considered it as rather uniform and only useful for separating species. As other inner organs were not known at that time, Pace called the family, exceedingly homogeneous, and so did Risbec (1954, p. 132) adding "as far as can be judged from the few dissected species". By the present dissections and microtomic studies the homogeneneity becomes considerably restricted.

For the most part the inner organs of the Columbellidae are buccinacean. This is shown by the salivary glands, the gland of Leiblein and its posterior elongation. Though a prominent pharynx of Leiblein is not developed in Buccinum (Graham, 1941, p. 12), it is not a divergent feature, because it occurs in the buccinid genus Pisa$n a$, as Mr. Edmund H. Smith recently verified in our Department. The muricacean effect of torsion (ibid., f. 2) does not occur in the pyriform pharynx of Leiblein of Pisania nor in our columbellids. It seems that this character distinguishes Muricacea and Buccinacea better than the shape of this pharynx.

The stomach of Buccinum (Dakin, 1912, f. 12, 13) and that of the Nassariidae Nassarius (Graham, 1949, f. 22) and Cyclope (Morton, 1960, f. 5) has a caecum, and is thus different from that of cur columbellids. The loss of the caecum is a specialization (Graham, 1949, p. 749). The gastric shield present in the mentioned nassariids and our columbellids is a primitive character in Steno- 
glossa. On the whole the Buccinacea are not as highly specialized in their diet as the shell-boring and suctorial feeding Muricacea (Morton, 1960 , p. 104). This is confirmed by our columbellids which comprise the carnivorous species 1-6 and the herbivorous mercatoria and rustica.

Oral cuticle, mobility, breadth and thick support of the radula, stronger teeth, salivary reservoirs, proboscideal glands opening into anterior oesophagus and radular pouch, as well as strenghtened and more extended gastric shield characterize our algae-feeding snails.

The central nervous system agrees essentially with the highly concentrated one of Buccinum. The coalesced buccal ganglia without commissure and the broadly connected cerebral ganglia in species 1-6 attain an even higher degree of concentration than Buccinum. The nervous system of the herbivorous species with cerebral commissure is a little less concentrated. The farther distant position of the supraintestinal ganglion in C. versicolor studied by Risbec (1954) was mentioned above.

Though only known since Tertiary times, hence relatively new, the columbellids have conquered an enormous extension of the littoral and even penetrated into deep water (Watson, 1886, p. 236-38, 240) . To their vast distribution from the Arctis to the Subantarctis corresponds the great number of species. This success is due to the organization of these mobile snails which quickly respond to any stimulus . The narrow peduncle of the foot and the concentrated, extremely zygoneurous central nervous system may be correlated with the efficiency of movements and reactions. Specialized are also the lateral teeth of the radula which probably function as tweezers.

The reproductive system combines extreme features, primitive cres as a gonopericardial-pallial communication, homologous to a right ureter, and secondary novelties as a pouch lodging the resting penis. Contrary to the radula whose wider and narrower interspaces between the lamellae of the lateral teeth do not divide the family into two distinctly separated groups the reproductive system allows for such a classification. The valid names of these groups cannot be established, as long as the generative organs are unknown for the type-species of the genera and subgenera belonging to them. 
The first group comprises brasiliana, sparsa, dichroa, and veleda. In this group the males have a seminal vesicle (rv), but no prostate; the females have an albumen gland (az) and sperm-receiving organs (ur) which belong to the efferent reproductive organs. The second group includes lunata, obesa, mercatoria, and rustica. The males have no seminal vesicle, but a prostate $(\mathrm{q})$; the females have no albumen gland, and the pericardium (ca) contains sperm.

Within the first group it is possible that the names Nitidella for dichroa and Anachis for the 3 other species can be maintained, because dichroa has a smooth vestibule (v), and pouches are formed by the canal of the bursa, while in the others the pouches are vestibular.

For a subdivision of the second group the gonopericardial-pallial connection cannot be used, because it is not always absent in lunata. It seems better to separate mercatoria and rustica as taxon without penial pouch, possibly maintaining for them the name Columbella as Abbott (1955) and Warmke \& Abbott (1961) do. The two other species, with penial pouch, are different in their prostates, paired and free in lunata, simple and intercalary' in obesa. If Mitrella scripta (L.) turns out to have two free prostates, lunata can preserve its generic name.

Though the anatomical study will perhaps lead to some alterations in generic and subgeneric names, the coincidence of anatomical and conchological cuts in the majority of cases obliges to recognize the taxonomic competence of the past century's conchologists.

\section{RESUMO}

Estudámos 1) Anachis brasiliana, 2) A. sparsa, 3) A. obesa, 4) A. veleda (têrmo popular: "felicidade"; nome não certo: lyrata), 5) Nitidella dichroa, 6) Mitrella lunata, 7) Columbella mercatoria e 8) C. rustica. Espécies 1-6 ocorrem durante o ano inteiro em Sargassum cymosum stenophyllum na Base de Pesquisas de Ubatuba (Enseada co Flamengo) do Instituto Oceanográfico da Universidade de São Paulo. Columbella mercatoria obtivemos na Ponta da Prainha, na costa do Canal de São Sebastião, perto do Bairro de São Francisco; C. rustica, de Nápoles. 
Verrugas e calo no lábio interno da concha e dentículos no externo não são taxonômicamente importantes, pois com crescimento If nto desenvolvem-se; com rápido, não. Também a configuração da concha e, segundo Pace (1902b), a escultura variam grandemente. Pelo ângulo apical da concha define-se como estreita a cavidade palial das espécies 1-6.

Os olhos, do tipo de Murex, situam-se nos tentáculos, látero-basalmente. A glândula pedal ventral difere pouco nos dois sexos đe sparsa; em dichroa, brasiliana, e veleda é maior na fêmea. Em oposição às duas pequenas espécies de Risbec (1954), as nossas tém tôdas opérculo. Ocorre também em tôdas a glândula pedal posterior. Esta produz o cordão de muco com que os animais se seguram trepando nas algas ou descendo do filme da superfície da água. Às mais das vêzes, as espécies pequenas rastejam continuada e ritmicamente; as maiores, também arritmicamente, aos passos.

Numerosas lacunas sanguíneas no teto da cavidade do manto sugerem função respiratória auxiliar desta região. Cilios no assoalho cia dita cavidade intensificam a correnteza exalante.

A concentração do anel nervoso abrange também comissura e ccnectivos bucais; os gânglios subintestinal e pleural direito coales$\mathrm{c} \in \mathrm{m}$-se. Sòmente nas espécies algófagas, mercatoria e rustica que comem Rhodomelaceae, existe comissura cerebral supra-esofágica; nas outras, carnívoras, os gânglios cerebrais tocam-se. Ainda as espécies herbívoras distinguem-se das carnívoras pela cutícula ao redor da bôca, rádula mais larga, mais móvel, de dentes mais grossos e suForte mais firme, pelos reservatórios das glândulas salivares, número maior de glândulas esofágicas, e escudo gástrico mais desenvolvido. As espécies carnívoras comem políquetos, crustáceos e arrancam a parte abdominal de ascídias compostas.

Tubo posterior alongado da glândula de Leiblein entra no rim que corresponde ao dos Pycnonephridia (Perrier).

Os órgãos reprodutivos permitem reconhecer dois grupos de espécies, o primeiro compreende brasiliana, sparsa, veleda, e dichroa; c segundo obesa, lunata, mercatoria, e rustica. O primeiro tem vesícula seminal não ciliada nem glandular no duto eferente interno. glândula de albumina, receptáculo seminal ou bôlsa copulatória nc cviduto, sendo ausentes próstáta e, na fêmea, duto gonopericardial. 
O segundo tem próstata no duto eferente palial, duto gonopericardial feminino, e pericárdio armazenador de espérmios, não ocorrendo vesícula seminal interna, glândula de albû̉mina, e órgãos espérmi-receptores no oviduto.

Comunicação do duto eferente renal com a cavidade palial ocorre en: tôdas as espécies; espérmios dispirenos faltam sòmente em obesa $\mathrm{e}$ lunata. Em sparsa, o orifício nidamental do vestíbulo e o vaginal da bôlsa copulatória são separados; dichroa possui divertículos no črnal da bôlsa copulatória, não no vestíbulo como as outras espécies do primeiro grupo.

No segundo grupo há um par de próstatas livres em lunata; uma iritercalar comprida, nas outras espécies. Excepcionalmente em $l u$ nata (em 1 fêmea de 10 microtomizadas), regularmente nas outras, existe ligação gonopericardial-palial, morfològicamente, ureter direito. Duto renopericardial largo e abertura renal glandular ocorrem nas fêmeas de lunata e obesa.

Afora em mercatoria e rustica, a metade externa do pênis em repouso situa-se numa bôlsa da cavidade palial. A bôlsa estende-se da glândula hipobranquial até a região renal; evidentemente a bôlsa alivia a correnteza respiratória e a eliminação dos produtos da digestão e excreção, pois o grosso órgão copulador masculino desocupa a cavidade do manto, não larga nas espécies 1-6.

As cápsulas ovulares de brasiliana, sparsa, e veleda, contêm sòmente ovos regulares, não alimentares. A concha dos velígeres tem uma volta e meía; a protoconcha adulta, 3-4 voltas. Daí depreendese vida pelágica durante certo tempo dos velígeres. As cápsulas de obesa e lunata incluem apenas um ovo.

\section{REFERENCES}

ABBOTT, R. Tucker, 1955 - American Seashells. XIV + 541 p., 40 pl. New York (D. van Nostrand).

AMAUDRUT, Alexandre, 1898 - La partie antérieure du tube digestif et la torsion chez les Mollusques Gastéropodes. Ann. Sci. Nat. Zool. sér. 8, v. 7, p. 1-291, pl. 1-10. Paris.

ANKEL, Wulf Emmo, 1926 - Der Spermatozoendimorphismus einiger Melaniiden. Biol. Zentralbl. v. 46 (3), p. 145-156, 6 textf. Leipzig.

- 1930 - Die atypische Spermatogenese von Janthina. Ztschr. Zellf. mikrosk. Anat. v. 11, p. 491-608, 61 textf., pl. 6-7. Berlin. 
- 1959 - Beobachtungen an Pyramidelliden des Gullmar-Fjordes. Zool. Anz. v. 162 , p. 1-21, 13 textf. Leipzig.

ARVY, L. 1952 - Contribution à l'étude des Trématodes parasites de Columbella rustica. Ann. Paras. hum. comp. v. 27, p. 485-498, pl. 1-2. Paris.

EENTHEM JUTTING, Tera van, 1927 - Marine Molluscs of the Island of Curaçao. Bijdr. Dierk. Afl. 25, p. 1-36, 5 textf. Amsterdam.

BFRNARD, F., 1890 - Recherches sur les crganes palléaux des Gastéropodes prosobranches. Ann. Sci. Nat. Zool. sér. 7, v. 9, p. 89-404, pl. 6-15. Paris.

ECUVIER, E. L., 1887 - Système nerveux, morphologie générale et classification des Gastéropodes prosobranches. Ann. Sci. Nat. Zool. sér. 7, v. 3, p. 1-510, pl. 1-19. Paris.

CARCELlES, A., 1944 - Catalogo de los moluscos marinos de Puerto Quequén. Rev. Mus. La Plata (n. ser.), Zool. v. 3, p. 233-309, pl. 1-15. La Plata.

COOKE, A. H., 1895 - Molluscs. The Cambridge Natural History, v. 3, XI + 459 p., 311 textf. London (MacMillan).

COOMANS, H. E., 1958 - A survey of the littoral Gastropoda of the Netherlands Antilles anıl other Caribbean Islands. Stud. Fauna Curaçao, 8, p. 42-111, pl. 1-16. Amsterdam.

CLÉNOT, Lucien, 1914 - Les organes phagocytaires des Mollusques. Arch. Zool. expér. génér. v. 45 (9), p. 267-305, pl. 10-13. Paris.

DAKIN, William J., 1912 - Buccinum (The Whelk). L. M. B. C. Mem. 20, VIII +115 p., 8 pls. London.

I'ALL, William Healey, 1889 - Report on the Mollusca ("Blake") II. Gastropoda and Scaphopoda. Bull. Mus. Comp. Zool. v. 18, p. 1-492, pl. 10-40. Cambridge, Mass.

— 1890 - Scientific Results of... "Albatross". Mollusca and Brachiopoda. Proc. U. S. Nat. Mus. Washington v. 12 (1889), p. 219-362, pl. 5-14. Washington, D. C.

FISCHER, P., 1887 - Manuel de Conchyliologie. XXIV + 1369 p., 23 pl. Paris (F. Savy).

— , \& BOUVIER, E.-L., 1892 - Recherches et considérations sur l'asymétrie des Mollusques univalves. Journ. Conchyl. v. 40, p. 117-207, pl. 1-3. Paris.

FRETTER, Vera, 1941 - The genital ducts of some British stenoglossan prosobranchs. Journ. Mar. Biol. Assoc. Unit. Kingd. v. 25 (1), p. 173-211, 6 textf. Cambridge.

— 1946 - The genital ducts of Theodoxus, Lamellaria and Trivia, and a discussion on their evolution in the prosobranchs. Journ. Mar. Biol. Assoc. Unit. Kingd. v. 26 (1947) (3: 1946), p. 312-351, 7 textf. Cambridge.

- 1948 - The structure and life history of some minute prosobranchs of rock pools, etc. Journ. Mar. Biol. Assoc. Unit. Kingd. v. 27, p. 597-632, 6 textf., pl. 4. Cambridge. 
1951 - Observations on the life history and functional morphology of Cerithiopsis tuberculata (Montagu) and Triphora perversa (L.). Journ. Mar. Biol, Assoc. Unit. Kingd. v. 29, p. 567-586, 6 textf. Cambridge.

- 1951 a - Some observations on the British cypraeids. Proc. Malac. Soc. v. 29 (1), p. 14-40. London.

- 1953 - The transference of sperm from male to female prosobranch, with reference, also, to the pyramidellids. Proc. Linnean Soc. London, sess. 164, 1951-52, pt. 2, p. 217-224, 3 textf. London.

—_ \& PATIL, A. M., 1958 - A revision of the systematic position of the prosobranch Cingulopsis ( $=$ Cingula) fulgida (J. Adams). Proc. Malac. Soc. v. 33 (3), p. 114-126, 4 textf. London.

GOFFERJE', Carlos N., 1950 - Contribuição à zoogeografia da malacofauna do litoral do Estado do Paraná. Arq. Mus. Paran. v. 8, p. 221-282, pl. 31-35. Curitiba (Brazil).

GRAHAM, Alastair, 1941 - The oesophagus of the stenoglossan prosobranchs. Proc. R. Soc. Edinb. v. 61, p. 1-23, 5 textf. Edinburgh \& London.

- 1949 - The molluscan stomach. Tr. R. Soc. Edinb. v. 61, pt. 3 (27), p. 737-778, 24 textf. Edinburgh \& London.

- 1954 - Some observations on the reproductive tract of Ianthina janthina (L.). Proc. Malac. Soc. v. 31 (1), p. 1-6, 3 textf. London.

- 1955 - Molluscan diets. Proc. Malac. Soc. v. 31, p. 144-159. London.

- 1957 - The molluscan skin with special reference to prosobranchs. Proc. Malac. Soc. v. 32, p. 135-144. London.

IfABE, Tadashige, 1944 - On the eggs and development of Japanese marine gastropods (1). Shell Stud. Magazine v. 13, p. 187-194. Tokyo.

HANSON, Jean, RANDALL, J. T. \& BAYLEY, S. T., 1952 - - The microstructure of the spermatozoa of the snail Viviparus. Exp. Cell Research v. 3, p. 65-78, 3 textf., 4 pl. New York.

FiANSTRÖM, Bertil, 1928 - Vergleichende Anatomie des Nervensystems der wirbellosen Tiere. XI +628 p., 650 textf. Berlin (J. Springer).

FEILPRIN, Angelo, 1887 - Explorations on the west coast of Florida and in the Okeechobee wilderness. Transact. Wagner Free Inst. Sci. v. 1, p. 1-134, pl. 1-19. Philadelphia.

HESSE, Richard, 1934 - Sinnesorgane (Anatomie). Handw. Naturw. 2nd. ed. v. 9, p. 4-52, 81 textf. Jena (Gustav Fischer).

HYMAN, O. W., 1925 - Natural partial fertilization in Fasciolaria tulipa. Journ. Morphol. Physiol. v. 41, p. 267-281, pl. 1-3. Philadelphia.

JOANNIS, L. de, 1834 - Sur l'animal de Columbella rustica. Mag. Zool. v. 4, Classe V, pl. 51. Paris.

JOHANSSON, J., 1939 - Anatomische Studien über die Gastropodenfamilien Rissoidae und Littorinidae. Zool. Bidr. v. 18 (1938-1940), p. 287-396, pl. 1-11. Uppsala. 
- 1957 - Notes on the littorinacean and stenoglossan genital organs, and a comparison with the Rissoacea. Zool. Bidr. v. 32, p. 81-91, 8 textf. Uppsala. JUHNSON, C. W., 1934 - List of marine Mollusca of the Atlantic coast from Labrador to Texas. Proc. Boston Soc. Nat. Hist. v. 40, p. 1-204. Boston.

KEEN, A. Myra, 1958 - Sea Shells of Tropical West America. VIII + 626 p. 10 pl. University Press, Stanford.

K.OBELT, Wilhelm, 1897 - Martini-Chemnitz, Conch. Cab., 2nd ed. v. 3, 1. Abthlg. d, 344 p., 44 pl. Nürnberg (Bauer \& Raspe, Emil Küster).

I.AMY, Ed., 1941 - Notes sur la distribution géographique du Columbella cribraria (Moll. Gastrop.). Bull. Mus. Nat. Hist. Natur. sér. 2 v. 13 (4), p. $306-$ 308. Paris.

LANGE DE MORRETES, Frederico, 1949 - Ensaio de catálogo dos moluscos do Brasil. Arq. Mus. Paran. v. 7, p. 5-216. Curitiba (Brazil).

IINKE, Otto, 1933 - Morphologie und Physiologie des Genitalapparates der Nordseelittorinen. Wiss. Meeresunters. N. F., Abtlg. Helgoland, v. 19, Heft 2 (5), p. 1-60, pl. 1-8. Kiel \& Leipzig.

MACPHERSON, J. Hope and CHAPPLE, E. H., 1951 - A systematic list of the marine and estuarine Mollusca of Victoria. Mem. Nat. Mus. n. ${ }^{\circ} 17$, p. 107-185. Melbourne.

NiARCUS, Eveline \& Ernesto, 1959 - Studies on Olividae. Bol. Fac. Fil., Univ. Zoologia n. ${ }^{\circ} 22$, p. $99-188,11$ pl. São Paulo.

MARTENS, Eduard von, 1897 - Conchologische Miscellen II. Arch. Naturg. Jahrg. 63, p. 157-180, pl. 15-17. Berlin .

MELVILL, J. Cosmo, 1881 - List of Mollusca obtained in South Carolina and Florida, principally at the island of Key West. Journ. Conch. v. 3, p. 155173. London \& Leeds.

MORTON, J. E., 1960 - The habits of Cyclope neritea, a style-bearing stenoglossan gastropod. Proc. Malac. Soc. v. 34 (2), p. 96-105, textf. 1-5. London. NOBRE, Augusto, 1938-1940 - Moluscos marinhos e das águas salobras. Fauna Malacologica de Portugal. XXXII + 808 p., XIX +87 pl. Pôrto (Comp. Ed. Minho, Barcelos).

ORBIGNY, Alcide d', 1835-1846 - Voyage dans l'Amérique Méridionale. v. 5, 3e partie Mollusques. Atlas 1846. Paris \& Strasbourg.

PACE, S., 1902a - On the anatomy and relationships of Voluta musica, Linn.; with notes on certain other supposed members of the Volutidae. Proc. Malac. Soc. v. 5 (1903), p. 21-31, pl. 2. London.

- 1902b - Contributions to the study of the Columbellidae. Proc. Malac. Soc. v. 5, p. 36-154. London.

PAGENSTECHER, H. Alex, 1863 - Untersuchungen über niedere Seethiere aus Cette. Zeitschr. wiss. Zool. v. 12 (3: 1862) p. 265-311, pl. 25-29. Leipzig. I LLSENEER, Paul, 1906 - Biscayan Plankton collected during a cruise of $\mathrm{H}$. M. S. "Research" 1900. VII - Mollusca. Tr. Linnean Soc. London ser. 2, Zool. v. 10 (5), p. 137-157, pl. 10-12. London. 
PERRY, Louise M. \& SCHWENGEL, Jeanne S., 1955 - Marine shells of the western coast of Florida. 318 p., 55 pl. Ithaca, N. Y. (Paleontol. Res. Inst.) .

PETIT, G. \& RISBEC, Jean, 1929 - Sur la ponte de quelques Gastéropodes Prosobranches. Bull. Soc. Zool. France v. 54 (4), p. 564-570, 5 textf. Paris.

PHILIPPI, R. A., 1851 - Abbildungen und Beschreibungen neuer oder wenig bekannter Conchylien. v. 3, 220 p., 48 pl. Cassel.

PORTMANN, Adolf, 1926 - Le rôle du spermatozoide atypique dans la formation des oeufs nourriciers de Buccinum undatum. Arch. Zool. expér. génér. v. 65, Nates et Revue, n. ${ }^{\circ}$ 4, p. 103-124, 18 textf. Paris.

— 1927 - Die Nähreierbildung durch atypische Spermien bei Buccinum undatum L. Zeitschr. Zellf. Mikrosk. Anat. v. 5 (1-2), p. 230-243, 12 textf. Berlin .

— 1930 - Die Entstehung der Nähreier bei Purpura lapillus durch atypische Befruchtung. Zeitschr. Zellf. Mikrosk. Anat. v. 12 (1), p. 167-178, 12 textf. Berlin.

PUFFER, EIton L. \& EMERSON, William K., 1953 - The molluscan community of the oyster-reef biotope on the central Texas coast. Journ. Paleontol. v. 27 (4), p. 537-544, 1 textf., pl. 56.

REEVE, Lovell, 1859 - Conchologia Iconica, v. 11, Monograph of the genus Celumbella, 37 pl. London.

REICHENBACH-KLINKE, Heinz-Hermann, 1956 - Die Entwicklung der Larven bei der Bandwurmordnung Tetraphyllidea Braun 1900. Abh. Braunschw. Wiss. Ges. v. 8, p. 61-73, 7 textf. Braunschweig.

RISBEC, Jean, 1937 - Recherches anatomiques sur les Prosobranches de la Nouvelle-Calédonie. Ann. Sci. Nat. Zool. sér. 10, v. 20, p. 189-228, pl. 1-4. Paris.

- 1954 - Sur l'anatomie des Columbelles (Gastéropodes Prosobranches). Bull. Soc. Zool. France, v. 79 (2-3), p. 127-134, textf. A (1-14), B (1-6). Paris.

- 1955 - Considérations sur l'anatomie comparée et la classification des. Gastéropodes Prosobranches. Journ. Conchyliol. v. 95, p. 45-82, 22 textf. Paris.

ROBERTSON, Robert, 1957 - Gastropod host of an Odostomia. Nautilus v. 70 (3), p. 96-97, 1 textf. Philadelphia, Pa.

SILÉN, Lars, 1946 -- On two new groups of Bryozoz living in shells of molluscs. Ark. Zool. v. 38 B, n. ${ }^{\circ}$ 1, p. 1-7. Stockholm.

SiMROTH, Heinrich, 1896-1907 - Gastropoda prosobranchia, Bronn, Kl. Ordn. v. 3, Abt. 2, VII + 1056 p., 63 pl. Leipzig (C. F. Winter).

§MITH, Edmund H., 1960 - On a new polyclad commensal of prosobranchs. An. Ac. Bras. Ciênc. v. 32, n. ${ }^{\circ}$ 3-4, p. 385-390, 4 textfs. Rio de Janeiro. 
SOUZA LOPES, Hugo de \& ALVARENGA, Moacir, 1957 - Contribuição ao conhecimento dos moluscos da ilha Fernando de Noronha, Brasil. Bol. Inst. Oceanogr. v. 6 (1955), p. 157-196, pl. 1-3. São Paulo.

SOWERBY, G. B., 1844 - New species of Columbella. Proc. Zool. Soc. v. 12, p. 48-53. London.

- $1882-$ Descriptions of new species of shells in the collection of $\mathrm{Mr}$. J. Cosmo Melvill. Proc. Zool. Soc. London 1882, p. 117-121, pl. 5. London. STAIGER, H., 1950 - Zur Determination der Nähreier bei Prosobranchiern. Rev. Suisse Zool. v. 57, p. 496-503. Genève.

THIELE, Johannes, 1924 - Ueber die Systematik der Columbelliden. Arch. Molluskenk. v. 56 , p. 200-210, pl. 9. Frankfurt a. M.

- 1925-1926 - Mollusca. W. Kükenthal \& T. Krumbach, Handb. Zool. v. 5, p. 15-258, textf. 8-343. Berlin \& Leipzig (W. de Gruyter).

— 1931, 1935 - Handbuch der systematischen Weichtierkunde, v. 1; 2, VI + V, 1154 p. 897 textf. Jena (Gustav Fischer).

THORSON, Gunnar, 1940 - Studies on the egg masses and larval development of Gastropoda from the Iranian Gulf. Dan. Sci. Invest. Iran, pt. 3, p. 159238, 32 textf. Copenhagen (Ejnar Munksgaard).

TUZET, Odette, 1930 - Recherches sur la spermatogenèse des Prosobranches. Arch. Zool. expér. génér. v. 70, p. 95-229, pl. 4-12. Paris.

WARMKE, Germaine L. \& ABBOTT, R. Tucker, 1961 - Caribbean Seashells. $\mathrm{X}+346$ p., 44 pls. Narberth, Pennsylvania (Livingston Publishing Company).

WATSON, R. B., 1886 - Report on the Scaphopoda and Gasteropoda. Rep. Res. Challenger, Zool. v. $15, \mathrm{~V}+756$ p., 53 pl. London.

WEBER, Hermann, 1924 - Ueber arhythmische Fortbewegung bei einigen Prosobranchiern. Zeitschr. vergl. Physiol. v. 2, p. 109-121, textf. 1-5. Berlin.

- 1926 - Ueber die Umdrehreflexe einiger Prosobranchier des Golfes von Neapel. Zeitschr. vergl. Physiol. v. 3, p. 389-474, textf. 1-22. Berlin.

W. OODWARD, M. F., 1900 - Note on the anatomy of Voluta ancilla (Sol.), Neptuneopsis gilchristi Sby., and Volutilithes abyssicola (Ad. \& Rve.). Proc. Malac. Soc. v. 4 (1901), p. 117-125, pl. 10. London.

\section{EXPLANATION OF LETTERS}

a - salivary ampulla .

ai - supra-intestinal ganglion.

an - groove of anterior foot glands .

ao - aorta.

ar - anus.

au - auricle.

az - albumen gland.

$\mathrm{b}$ - ctenidium. c - columellar muscle .

ca - pericardium.

cc - buccal ganglia .

$\mathrm{cn}$ - capsule gland.

cs - radular pouch.

cz. - caps of small cells on cerebral ganglia .

d - efferent male duct .

e - oesophagus . 
ea - pedal ganglia.

ei - gland of Leiblein .

eo - penial pouch .

er - cerebral ganglia .

eu - pleural ganglia.

$\mathrm{f}$ - renal folds.

$\mathrm{g}$ - gonopericardial-pallial connection.

$\mathrm{i}$ - intestine.

io - oviduct.

is - gastric shield.

ir - intestinal groove.

iu -- subintestinal ganglion.

iv - glands of sole.

$\mathrm{j}$ - ejaculatory duct .

$\mathrm{k}$ - kidney .

1 - duct of digestive gland.

ma - posterior oesophagus.

me - mantle.

mi - minor typhlosole.

mir - furrow of foot.

ms - siphonal retractor.

mv - mantle border.

n - nerve.

na - nerves to anterior border of foot.

ni - renal aperture.

nn - tentacle nerve.

no - gonopericardial duct .

nv - posterior pedal nerves.

o - ovary.

oa -- nephridial and blood gland.

oc - operculum.

on - osphradial-branchial nerve.

oo - food string.

os - osphradium.
ow - duct of posterior foot gland. $x n-$ vestibular op

$\mathrm{p}$ - pallial cavity.

$\mathrm{q}-$ penis.

$\mathrm{r}$ - radular teeth.

ra - pallial connection of sperm duct. rc - radular cartilage.

re - renopericardial duct.

rm - major typhlosole.

ro - proboscis .

rs - prostatic gland.

rv - seminal vesicle.

$\mathrm{rz}$ - proboscis pouch .

$\mathrm{s}$ - salivary gland.

sa - sorting area.

sc - sole of foot.

se - sperm.

si - blood space.

sn - siphonal nerve.

so - siphon.

su — swelling of visceral loop.

sv - coiled part of sperm duct.

sw - siphonal ganglion.

sz - statocyst.

$t$ - tentacle .

$\mathbf{u}$ - female aperture.

ui - urinary chamber.

uo - posterior pedal gland.

ur - bursa copulatrix.

us - anterior diverticulum of radular sac.

$\mathrm{v}$ - vestibule.

va - visceral ganglia.

vc - visceral loop.

ve - ventricle.

vi - renal villosities.

vn - ventral pedal (moulding) gland.

w - salivary duct.

w1 - right pallio-parietal nerve.

$x$ - cilia .

$\mathrm{xi}$ - vestibular opening of sparsa.

y - hypobranchial gland.

$\mathrm{z}$ - blood vessel.

za - opercular pad.

zi - left zygosis.

Zs -- vestibular or bursal pouches. 
P L A T E S 


\section{PLATE 1}

Fig. 1 - Anachis brasiliana.

Fig. 2 - Anachis sparsa.

Fig. 3 - Anachis veleda.

Fig. 4 - Nitidella dichroa.

Fig. 5 - Columbella mercatoria.

Fig. 6 - Columbella rustica.

Fig. 7 - Sole of female veleda. 
E. \& E. MARCUS - COLUMBELLIDAE - PLATE 1
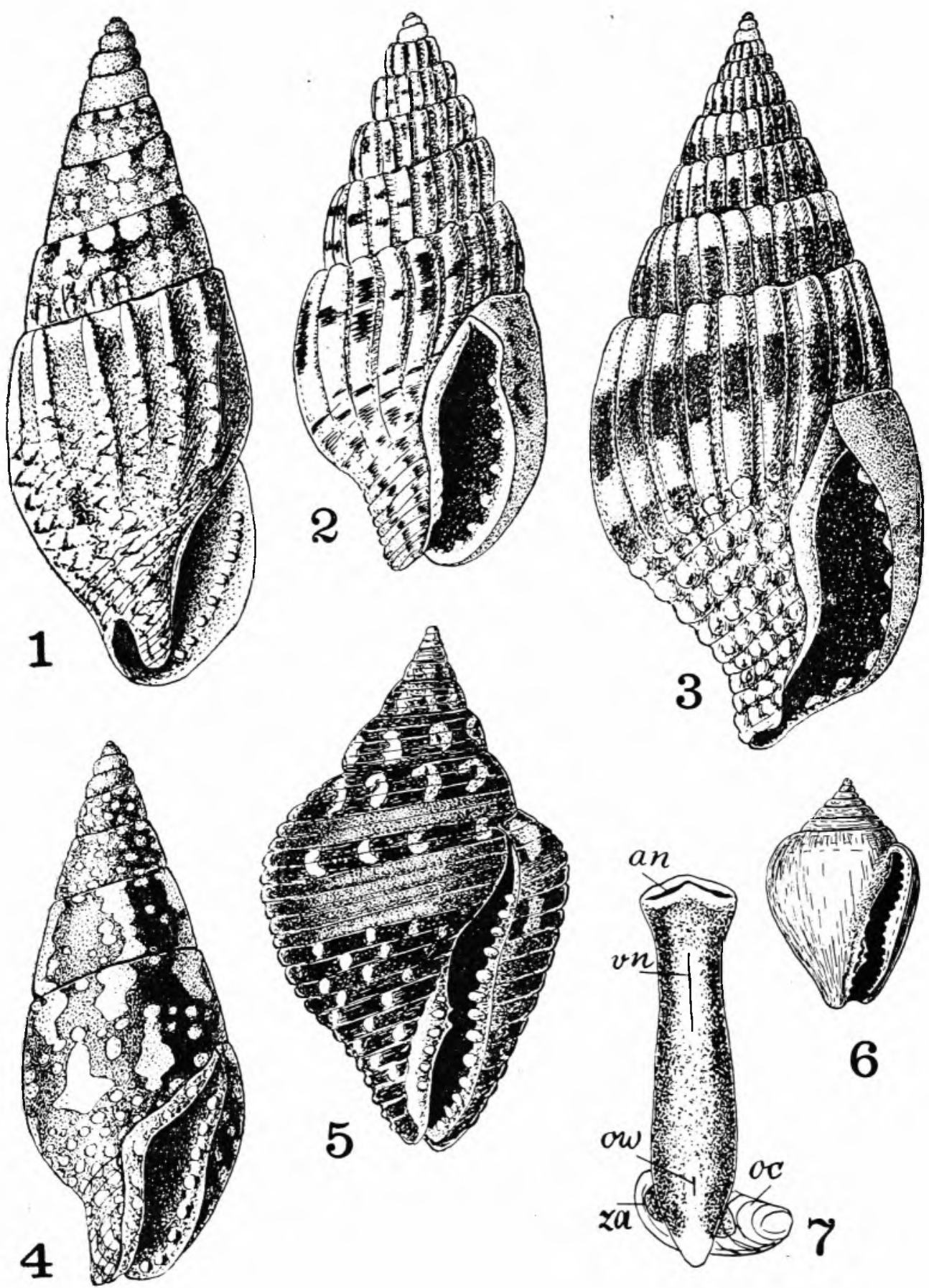


\section{PLATE 2}

Fig. 8 - Combined transverse section of male lunata.

Fig. 9 - Male sparsa removed from shell, pallial cavity opened.

Fig. 10 - Tip of proboscis with protruded radula of mercatoria.

Fig. 11 - Central nervous system of male veleda. 
E. \& E. MARCUS - COLUMBELLIDAE - PLATE 2
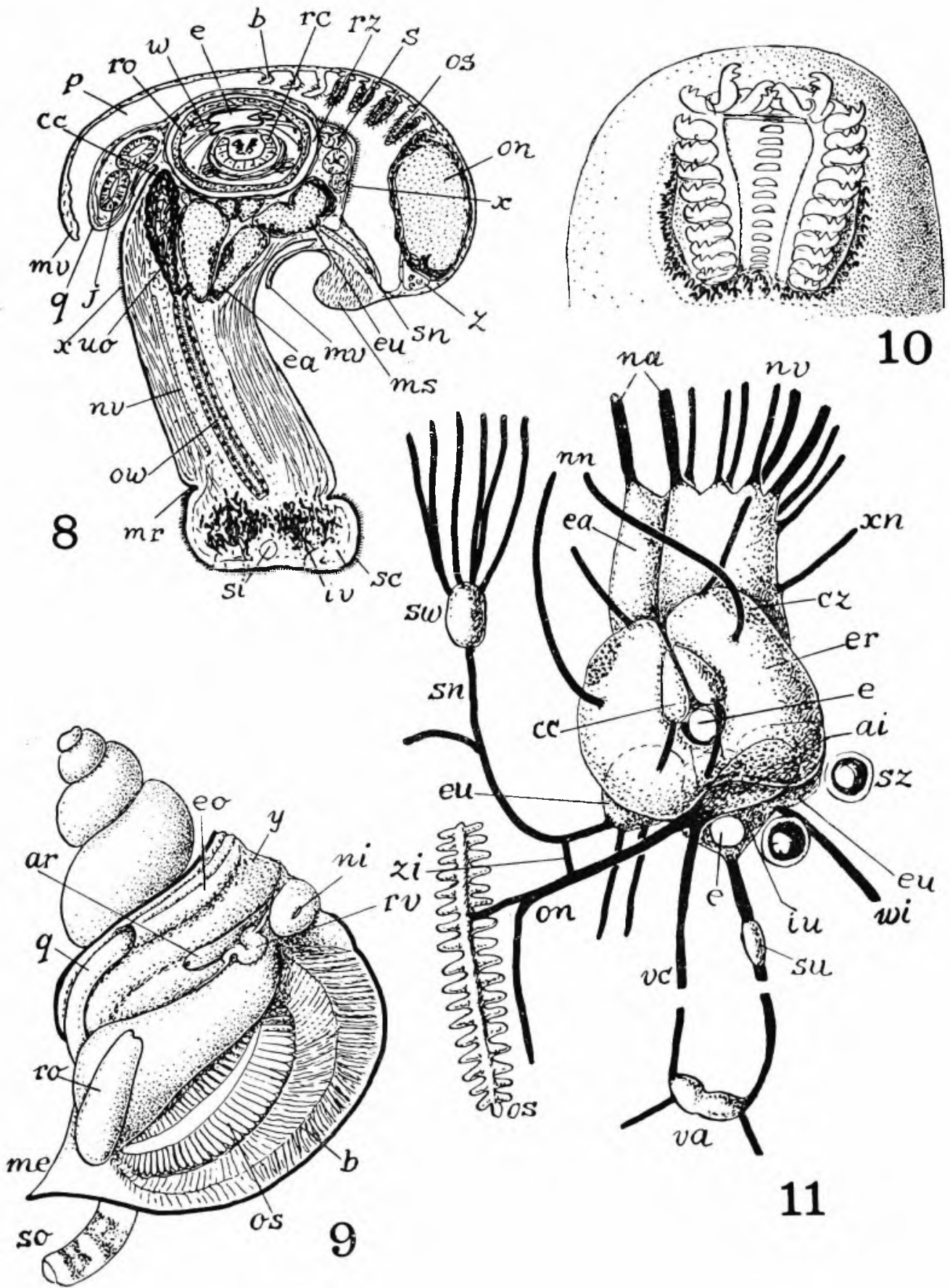


\section{PLATE 3}

Fig. 12 - Transverse section of proboscis of rustica, near tip.

Fig. 13 - Lateral radular tooth of brasiliana .

Fig. 14 - Same of sparsa.

Fig. 15 - Same of obesa.

Fig. 16 - Same of veleda.

Fig. 17 - Same of dichroa.

Fig. 18 - Same of lunata.

Fig. 19 - Three lateral radular teeth of mercatoria.

Fig. 20 - Same of rustica.

Fig. 21 - Stomach of veleda opened on dorsal side. 
E. \& E. MARCUS - COLUMbEllidaE - PLATE 3
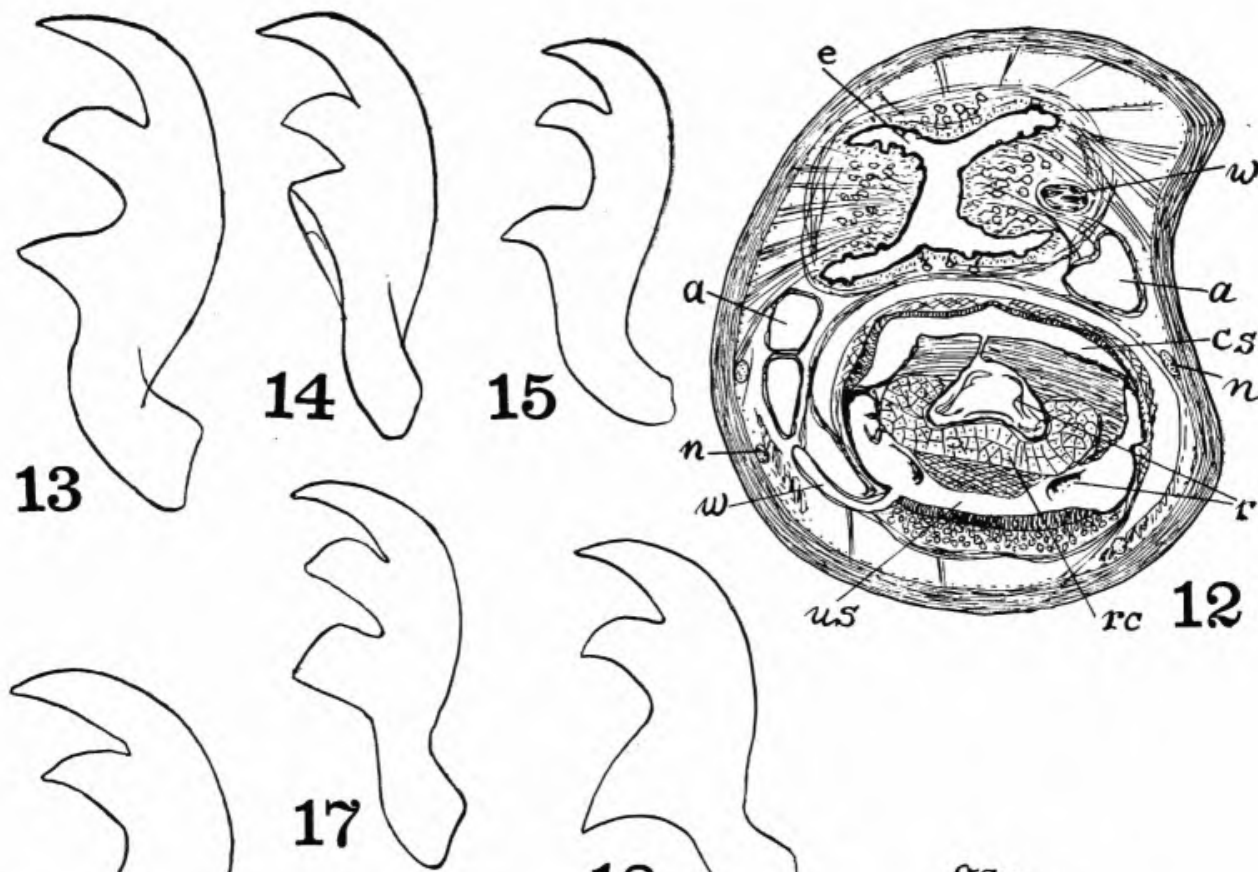

n

$n-10$ - w

w 1
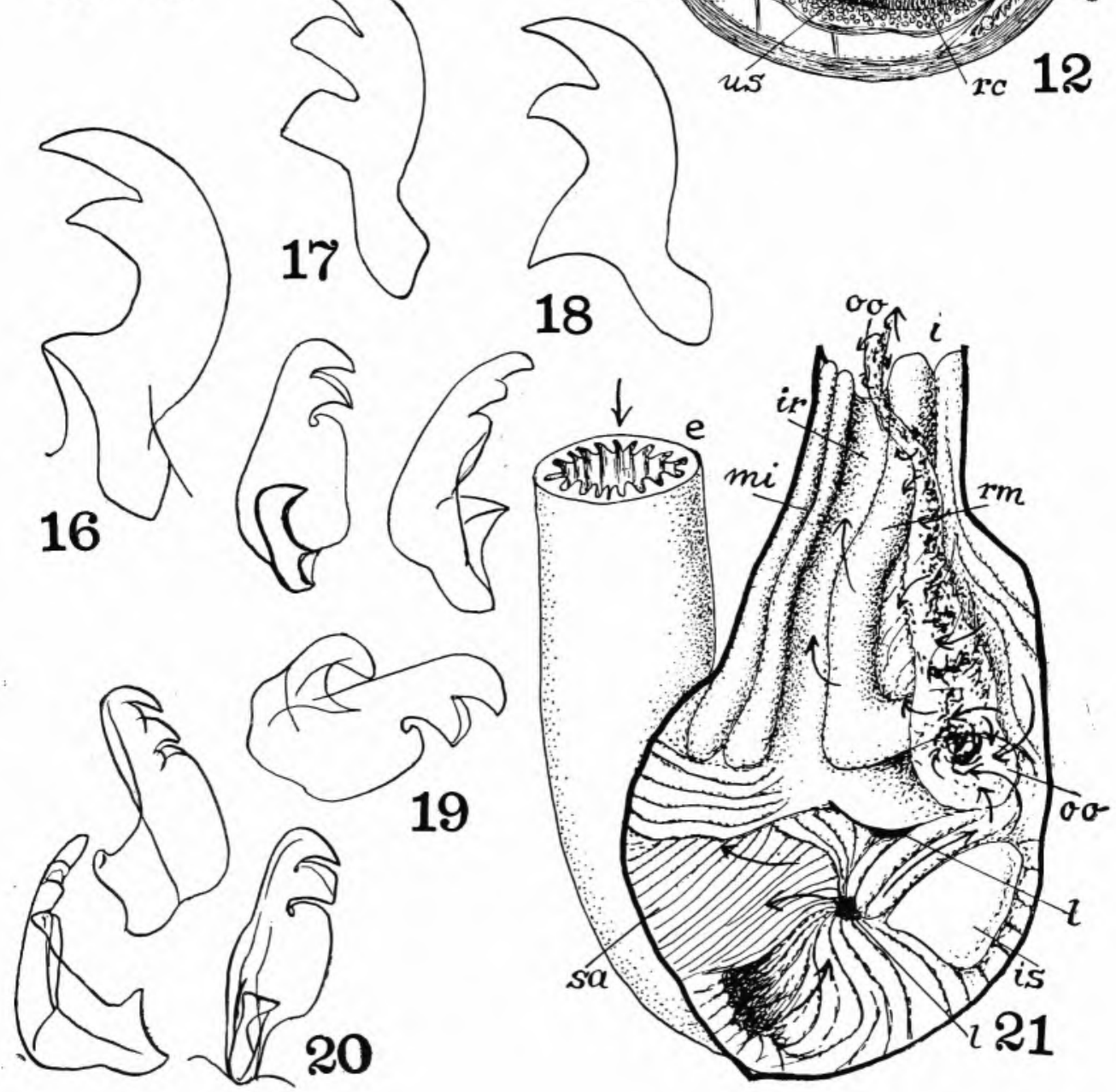


\section{PLATE 4}

Fig. 22 - dichroa removed from shell.

Fig. 23 - Diagram of male organs of mercatoria.

Fig. 24 - Same of rustica.

Fig. 25 - Reconstruction of middle sperm duct of brasiliana.

Fig. 26 - Same of sparsa.

Fig. 27 - Same of dichroa.

Fig. 28 - Same of veleda.

Fig. 29 - Same of lunata.

Fig. 30 - Same of obesa.

Fig. 31 - Diagram of male organs of lunata. 
E. \& E. MARCUS - COLUMBELLIDAE - PLATE 4
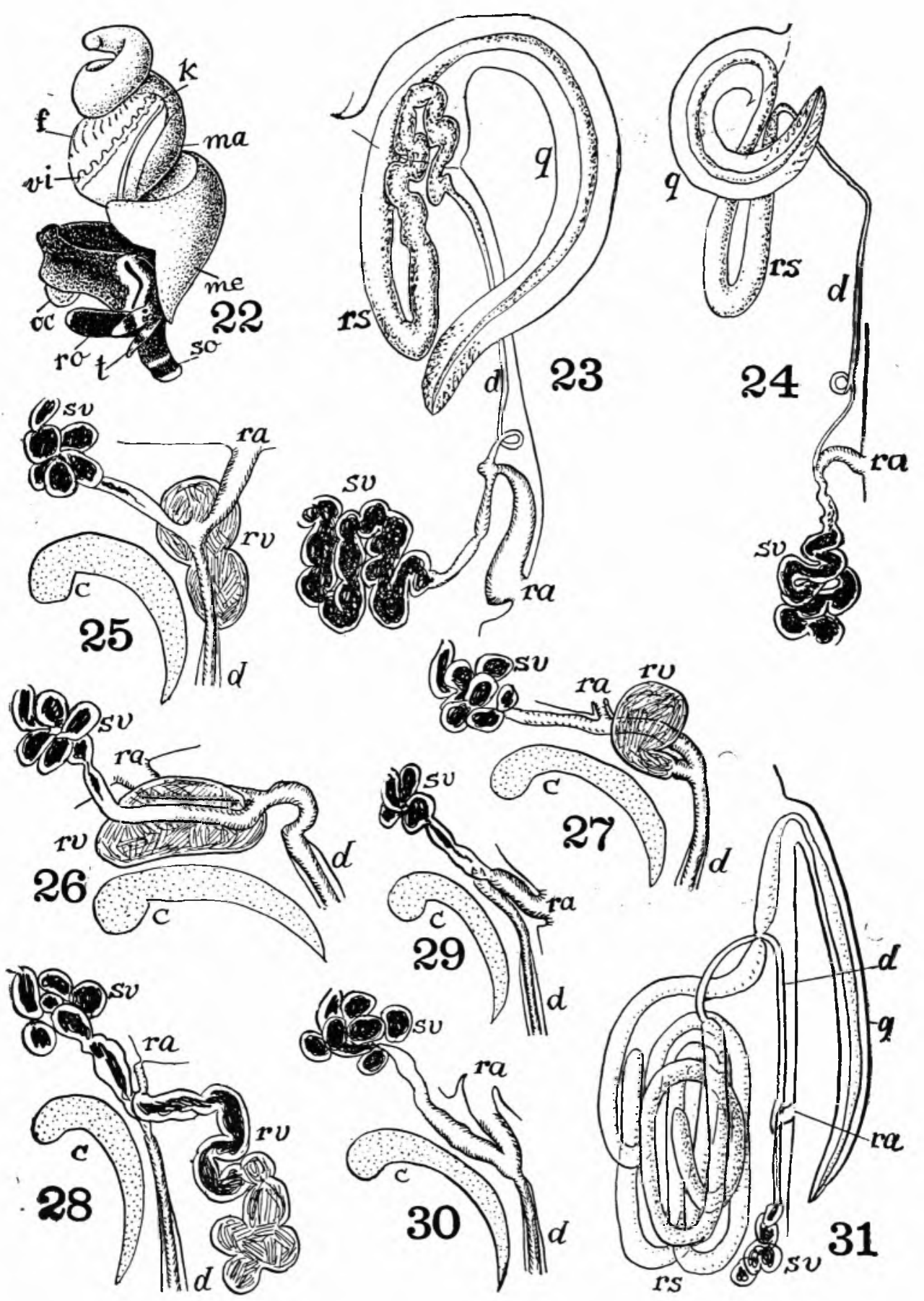


\section{PLATE 5}

Fig. 32 - Diagram of male organs of obesa.

Fig. 33 - Transverse section of male lunata.

Fig. 34 - Diagram of female organs of brasiliana.

Fig. 35 - Same of sparsa. 
E. \& E. MARCUS - COLUMBELlidAE - PLATE 5
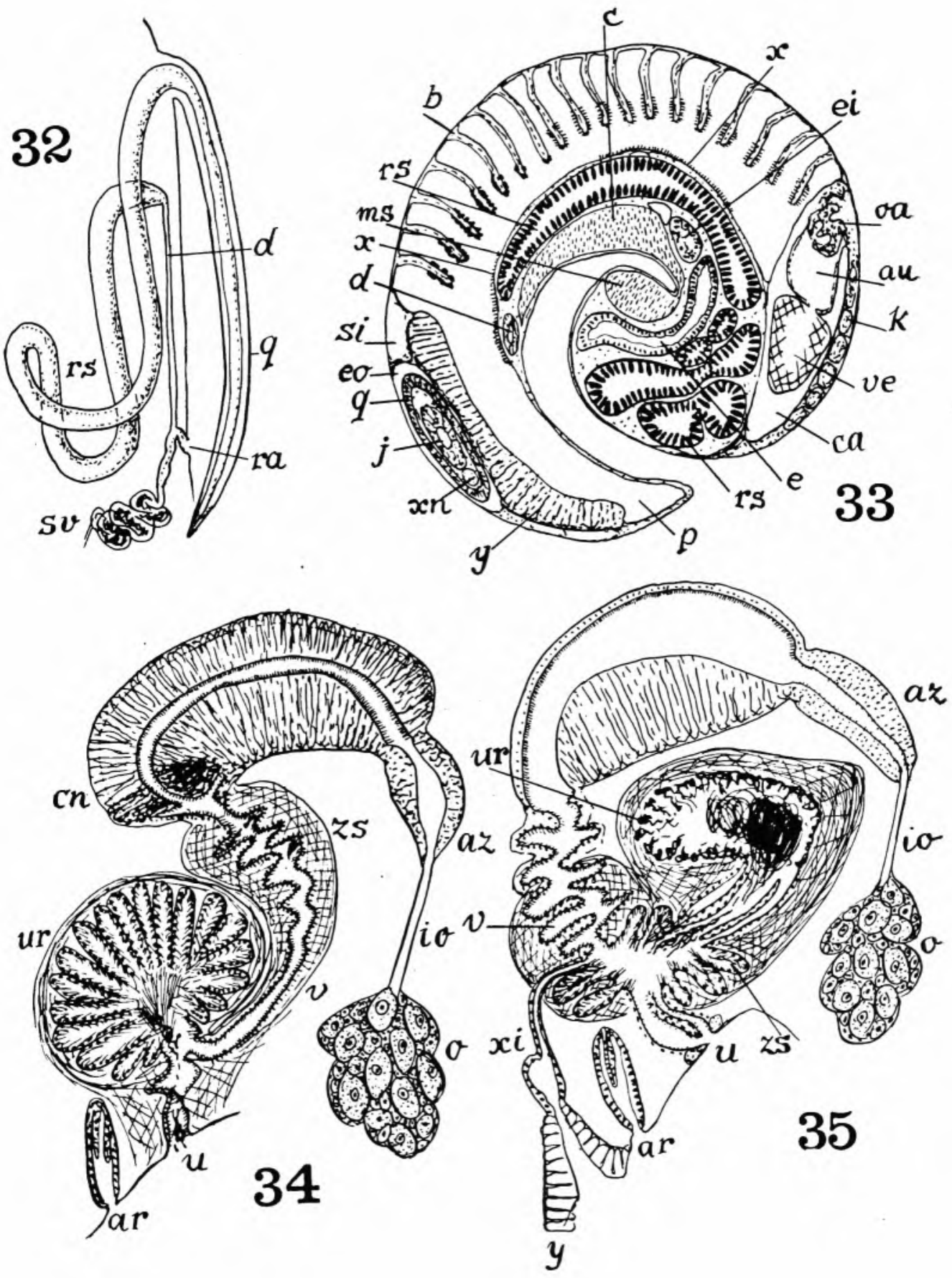


\section{PLATE 6}

Fig. 36 - Diagram of female organs of dichroa.

Fig. 37 - Same of veleda.

Fig. 38 - Same of lunata.

Fig. 39 - Exceptional gonopericardial-pallial connection in lunata.

Fig. 40 - Diagram of female organs of obesa. 
E. \& E. MARCUS - COLUMBELLIDAE - PLATE 6
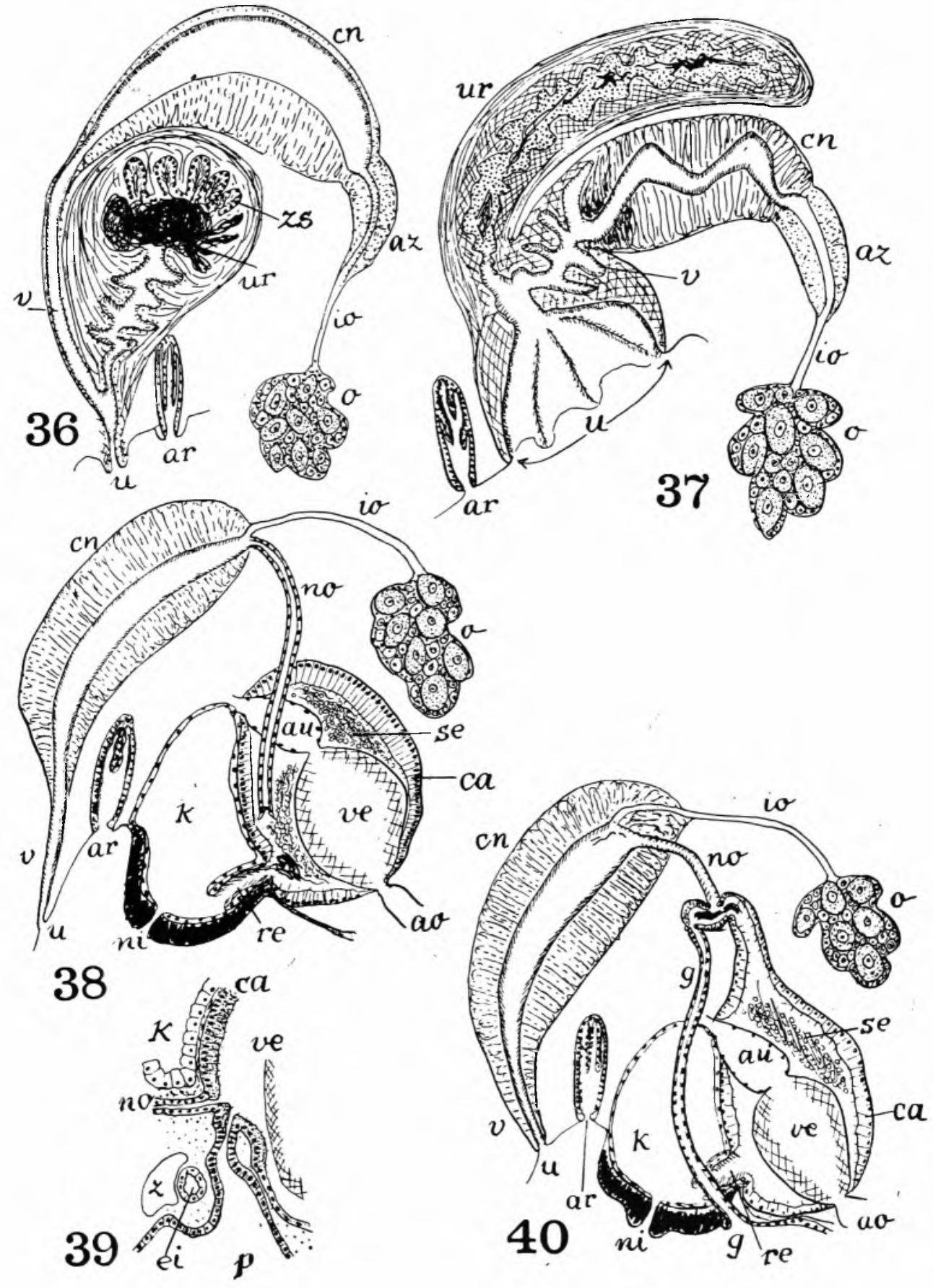


\section{PLATE 7}

Fig. 41 - Combined section of pericardium and neighbourhood in female obesa.

Fig. 42 - Diagram of female organs of mercatoria.

Fig. 43 - Same of rustica. 
E. \& E. MARCUS - COLUMBELLIDAE - PLATE 7

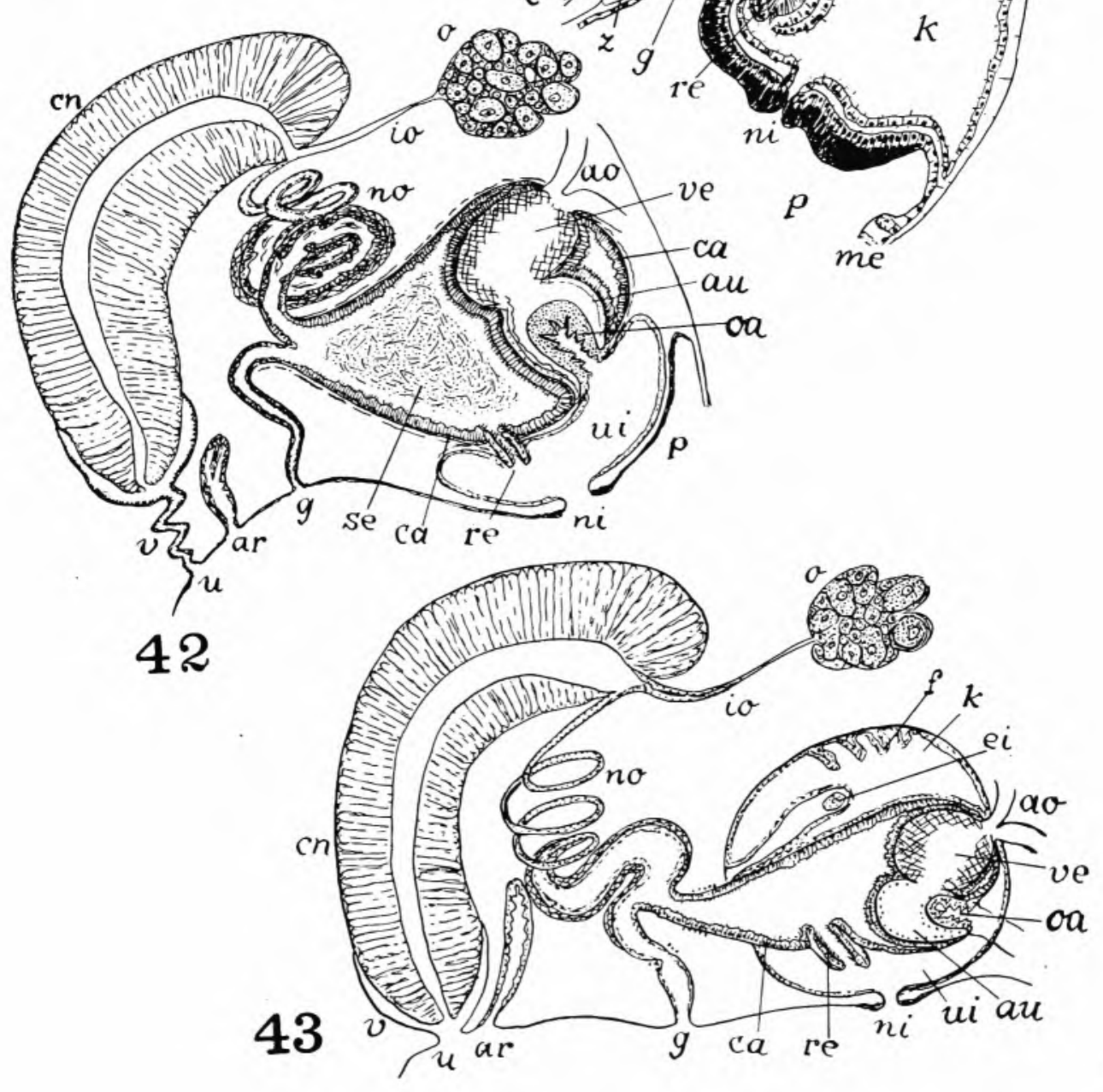




\section{PLATE 8}

Fig. 44 - Three egg capsules of sparsa.

Fig. 45 - Two egg capsules of brasiliana, seen from above.

Fig. 46 - Basal view of egg capsules of brasiliana with newly laid eggs and veliger shells.

Fig. 47 - Two egg capsules of brasiliana, side view .

Fig. 48 - Five eff capsules from a spawn of veleda.

Fig. 49 - Egg capsule of veleda, basal view.

Fig. 50 - Veliger of brasiliana.

Fig. 51 - Shell of same.

Fig. 52 - Shell of veliger of sparsa. 
E. \& E. MARCUS - COLUMBELlidaE - PLATE 8
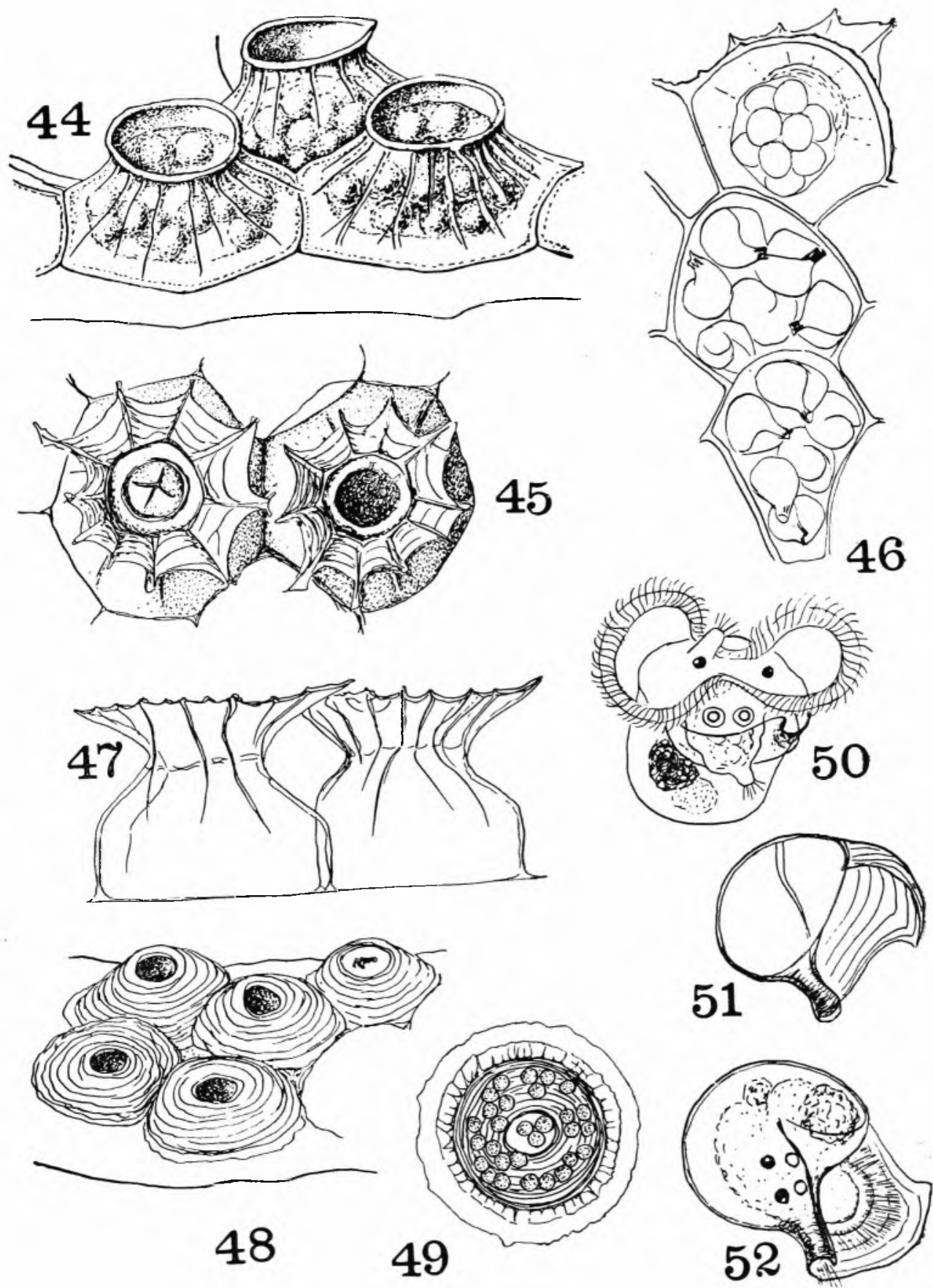